\title{
The choice of precursors in the synthesizing of CuMnOx catalysts for maximizing $\mathrm{CO}$ oxidation
}

\author{
Subhashish Dey ${ }^{1} \cdot$ Ganesh Chandra Dhal ${ }^{1} \cdot$ Devendra Mohan $^{1} \cdot$ Ram Prasad $^{2}$
}

Received: 7 November 2017 / Accepted: 13 August 2018 / Published online: 23 August 2018

(c) The Author(s) 2018

\begin{abstract}
The hopcalite $(\mathrm{CuMnOx})$ catalyst is a well-known catalyst for $\mathrm{CO}$ oxidation at a low temperature and it is synthesized by the co-precipitation method with different types of precursors. Activity of the CuMnOx catalysts for $\mathrm{CO}$ oxidation is strongly dependent upon the combination of precursors, ranking in order $\left\{\mathrm{Mn}(\mathrm{Ac})_{2}+\mathrm{Cu}\left(\mathrm{NO}_{3}\right)_{2}\right\}>\left\{\mathrm{Mn}(\mathrm{Ac})_{2}+\mathrm{Cu}(\mathrm{Ac})_{2}\right\}>\{\mathrm{Mn}(\mathrm{N}$ $\left.\left.\mathrm{O}_{3}\right)_{2}+\mathrm{Cu}\left(\mathrm{NO}_{3}\right)_{2}\right\}>\left\{\mathrm{Mn}\left(\mathrm{NO}_{3}\right)_{2}+\mathrm{Cu}(\mathrm{AC})_{2}\right\}$. All the precursors were precipitated by $\mathrm{KMnO}_{4}$ solution and the precursors mostly comprised of $\mathrm{MnO}_{2}, \mathrm{Mn}_{2} \mathrm{O}_{3}$ and $\mathrm{CuO}$ phases. Keeping the same precipitant while changing the precursors caused a change in the lattice oxygen mobility which influenced the $\mathrm{CO}$ oxidation activity. The calcination strategy of the precursors has great influence on the activity of resulting catalysts. The reactive calcination (RC) conditions produce multifarious phenomena of $\mathrm{CO}$ oxidation and the precursor decomposition in a single-step process. The activity order of the catalysts for $\mathrm{CO}$ oxidation was as follows: reactive calcination $(\mathrm{RC})>$ flowing air $>$ stagnant air. Therefore, we recommended that the $\mathrm{RC}$ route was the more appropriate calcination route for the production of highly active CuMnOx catalysts. All the catalysts were characterized by X-ray diffraction, Fourier transform infrared spectroscopy, Brunauer-Emmett-Teller analysis, X-ray photoelectron spectroscopy and scanning electron microscopy technique. The influence of precursors on the structural properties and the catalytic activity of co-precipitation derived binary $\mathrm{CuMnOx}$ catalysts for $\mathrm{CO}$ oxidation has been investigated.
\end{abstract}

Keywords Carbon monoxide · Hopcalite (CuMnOx) catalyst · Co-precipitation method · Calcination and characterization

\section{Introduction}

Carbon monoxide $(\mathrm{CO})$ is a poisonous gas that needs to be removed from the air. It is a colorless, odorless, tasteless and non-irritating gas, which makes it very difficult for humans to detect. Huge amounts of $\mathrm{CO}$ are emitted in the world, mainly from transportation, power plants, industrial and domestic activities [1,2]. The transportation sector contributes the largest source of $\mathrm{CO}$ emissions in the developed countries. In comparison to a diesel engine, the petrol engine vehicle produces more $\mathrm{CO}$ into the environment $[3,4]$. $\mathrm{CO}$ is formed in an internal combustion (I.C.) engine that is operated by the burning of fossil fuels (petrol or diesel), as an intermediate reaction during the incomplete combustion of

Subhashish Dey

subhasdey633@gmail.com

1 Department of Civil Engineering, IIT (BHU), Varanasi, India

2 Department of Chemical Engineering and Technology, IIT (BHU), Varanasi, India
$\mathrm{HC}$ [5]. The low temperature catalytic oxidation of $\mathrm{CO}$ is a very important process and it is essential in many applications such as in residential and automotive air-cleaning technologies, $\mathrm{CO}$ detectors, gas masks for firefighters, mining application and selective oxidation of $\mathrm{CO}$ in reformer gas for the fuel cell applications [6,7]. The performance of catalytic converter is highly dependent upon the type of catalyst was used. In the presence of a catalyst, the rate of chemical reaction is increase; it acts like an agent that reduces the activation energy of the reactions [8]. The noble metals ( $\mathrm{Pt}, \mathrm{Pd}$, $\mathrm{Rh}, \mathrm{Au}$, etc.) and base metals ( $\mathrm{Cu}, \mathrm{Mn}, \mathrm{Cr}, \mathrm{Co}, \mathrm{Ni}, \mathrm{Fe}$, etc.) were widely used as catalysts in the catalytic converter [9, 10]. Commercial catalysts that were mainly applied for $\mathrm{CO}$ oxidation present in the exhaust gas were noble metals. It has a high activity and thermal stability, so it was widely used as a catalyst in catalytic converter [11]. However, the employment of noble metal catalysts was limited due to their low availability, sulfur poisoning, and high cost [12]. Therefore, it was important to find an alternative catalytic component to replace the noble metal catalyst and attention has been given to base metals as catalysts. 
Compared to noble metal catalysts, the hopcalite (CuM$\mathrm{nOx}$ ) is one of the oldest known catalysts for $\mathrm{CO}$ oxidation at a low temperature. It is widely used for the respiratory protection systems in many types of applications like military, mining, and space devices, etc. The other practical advantages of hopcalite catalysts are cost efficiency, high availability, moisture resistance and high catalytic activity that results from their ability to provide an active oxygen species by changing oxidation states [13, 14]. In 1920 Lamb, Bray and Frazer discovered that various mixed oxides of $\mathrm{Cu}, \mathrm{Mn}, \mathrm{Ag}$, and $\mathrm{Co}$, and identified them as a group of catalysts known as hopcalite (CuMnOx) [15]. The structure of hopcalite catalyst is strongly dependent upon the preparation methods, $(\mathrm{Cu}: \mathrm{Mn})$ molar ratio, drying temperature and calcination conditions of the catalyst [16]. When oxygen species associated with copper in the CuMnOx catalyst was very active for the low temperature catalytic oxidation of $\mathrm{CO}$ [17]. The lattice oxygen mobility, specific surface area, and pore volume were highly effective on the activity of the catalysts for $\mathrm{CO}$ oxidation. To increase the reactivity of lattice oxygen associated with copper species as well as the mobility of lattice oxygen from the manganese species [18]. The CuMnOx catalyst has a high catalytic activity in $\mathrm{CO}$ oxidation that could be ascribed to the resonance system $\mathrm{Cu}^{2+}+\mathrm{Mn}^{3+} \rightleftarrows \mathrm{Cu}^{+}+\mathrm{Mn}^{4+}$ and the high adsorption of $\mathrm{CO}$ onto $\mathrm{Cu}^{2+} / \mathrm{Mn}^{4+}$ and of $\mathrm{O}_{2}$ onto $\mathrm{Cu}^{+} / \mathrm{Mn}^{3+}$ [19]. The $\mathrm{Cu}$ oxide was found to be poorly active for $\mathrm{CO}$ oxidation, but in conjunction with Mn oxide in appropriate proportions, some very active catalyst systems were generated [20].

Till date, there are various methods (i.e., co-precipitation, supercritical antisolvent precipitation, sol-gel, ultrasonic aerosol pyrolysis, and reduction) that have been implemented to prepare the CuMnOx catalysts. Among these methods, the conventional co-precipitation method can be use to produce the CuMnOx catalysts with high activity [21]. The screening of best precursor and successive calcination strategies of $\mathrm{CuMnOx}$ catalysts enhances their activity for $\mathrm{CO}$ oxidation [22]. Thus, the state of precursor varies depending on the types of chemicals that are use, which results in the development of calcined catalysts with different crystalline phases and different catalytic performances [23]. The high activity is due to the formation of $\mathrm{Cu}-\mathrm{Mn}$ spinel $\mathrm{CuMn}_{2} \mathrm{O}_{4}$ formed during the co-precipitation process. The redox reaction has been proposed to explain that the $\mathrm{CuMnOx}$ catalyst activity, i.e., an electronic transfer between copper and manganese cations within the spinel lattice [24]. The occurrence of individual phases and their quantitative proportions depend upon the temperature, $\mathrm{pH}$ and concentrations of the reactant solutions [25].

According to Hutching et al., the performance of CuMnOx catalysts very much depends upon the calcination conditions of the precursors and the subsequent pretreatment of the catalysts [26]. The high-temperature calcination causes sintering of the active crystallites with a consequent loss of surface area and subsequently adversely affects on the performance of the catalyst [27]. Therefore, to minimize the above-mentioned drawbacks of two steps of calcination and pretreatment, a newer route of single-step thermal treatment of the precursors in a reactive $4.5 \% \mathrm{CO}$-air mixture at a low temperature $\left(160{ }^{\circ} \mathrm{C}\right)$ has been recently suggested by the authors for preparing highly active catalysts by passing the separate pretreatment step [28]. This single-step thermal treatment of the precursor is called "RC method". It is postulated that the RC method parallel to multifarious phenomena of $\mathrm{CO}$ oxidation and precursor decomposition, causes a synergistic effect in the formation of oxygen-deficient catalyst at a low temperature. The success of $\mathrm{CuMnOx}$ catalyst has prompted a great deal of fundamental work devoted to clarifying the role played by each element and the nature of active sites. The activity of $\mathrm{CuMnOx}$ catalyst is highly dependent upon the structure and the preparation route [29]. Recently, Tang et al. have synthesized the nano-crystalline $\mathrm{CuMnOx}$ catalysts using the supercritical antisolvent precipitation method and found them to be more than twice as active as the conventionally prepared hopcalite catalysts for the $\mathrm{CO}$ oxidation [30]. They attributed the high catalytic activity to the nano-crystalline and homogeneous nature of the synthesized CuMnOx [31, 32]. The presence of manganese oxide is likely to facilitate the reduction of copper oxide, involving coordination between $\mathrm{CuO}$ and $\mathrm{MnO}_{2}$, the manganese oxide acting as an oxygen donor and copper oxide acting as the oxygen acceptor. A previous work demonstrated that the presence of $\mathrm{Cu}^{2+}$ and $\mathrm{Mn}^{3+}$ is essential for the high catalytic activity of CuMnOx catalyst [33, 34]. In present study, the different types of precursors have been used to change the crystalline phase of the catalysts and to find out the best $\mathrm{CuMnOx}$ catalyst, which will give the highest activity for $\mathrm{CO}$ oxidation.

\section{Experimental}

\section{Catalyst preparation}

The CuMnOx catalysts were prepared by the co-precipitation method. All the materials used for the preparation work were of analytical reagent (A.R.) grade. A solution of $\mathrm{Mn}(\mathrm{Ac})_{2}$ or $\mathrm{Mn}\left(\mathrm{NO}_{3}\right)_{2}(0.85 \mathrm{M})$ was added to $0.15 \mathrm{M}$ of $\mathrm{Cu}(\mathrm{Ac})_{2}$ or $\mathrm{Cu}\left(\mathrm{NO}_{3}\right)_{2}$ and stirred for $1 \mathrm{~h}$. The mixed solution was taken in the burette and added dropwise to a solution of $\mathrm{KMnO}_{4}(0.25 \mathrm{M})$ under the vigorous (continuous) stirring conditions for the co-precipitation purpose. The resultant precipitate was stirred continuously for $2 \mathrm{~h}$. In the previous research, the optimum molar ratio of $\mathrm{Cu}: \mathrm{Mn}$ in the $\mathrm{CuM}$ nOx catalyst was 1:8 [29]. The precipitates were filtered and washed several times with hot distilled water to remove all 
the anions. The cake thus obtained was dried at the temperature $110{ }^{\circ} \mathrm{C}$ for $24 \mathrm{~h}$ in the oven and calcined at $300{ }^{\circ} \mathrm{C}$ for $2 \mathrm{~h}$. All the precursors were calcined in three different ways; first following the traditional method of calcination in stagnant air at $300{ }^{\circ} \mathrm{C}$ just above the decomposition temperatures of the precursors for $2 \mathrm{~h}$ in a muffle furnace, second in situ calcination in flowing air at a rate of $32.5 \mathrm{ml} \mathrm{min}^{-1}$ at $300{ }^{\circ} \mathrm{C}$ for $2 \mathrm{~h}$. The third way calcination was carried out using the in situ reactive calcination (RC) as described. The reactive calcination of the precursors was carrying out in situ in a down-flow bench-scale tubular reactor with a defined amount of precursor that was diluted with $\alpha$-alumina to make a total volume of $1 \mathrm{ml}$ at atmospheric pressure. The nomenclature of the resulting catalysts thus formed was given by the first capital letter of the corresponding precursors use and the suffixes 'SA', 'FA' and 'RC' denote whether they were obtained by calcination in air, flowing air or by $\mathrm{RC}$, respectively, as presented in Table 1.

Reactive calcination of the precursor was carried out by the introduction of a low concentration of chemically reactive $\mathrm{CO}$-air mixture $(4.5 \% \mathrm{CO})$ at a total flow rate of $32.5 \mathrm{ml} \mathrm{min}{ }^{-1}$ over the hot precursors. The temperature of the reactor bed was increased from room temperature to $160{ }^{\circ} \mathrm{C}$ where $\mathrm{CO}$ conversion has started. This temperature was maintained for a defined period of time where the $\mathrm{CO}$ concentration was measured in the exit stream of the reactor at regular intervals until $100 \%$ CO conversion was achieved. After achieving total $\mathrm{CO}$ conversion, the resultant catalyst was annealed for half an hour at the same temperature, than the temperature was increased up to $300{ }^{\circ} \mathrm{C}$ and held for an hour followed by cooling down to room temperature in the same environment. The catalysts prepared as given above were stored in capped glass sample holders placed in desiccators.

Table 1 Calcination strategy and nomenclature of the catalysts

\begin{tabular}{|c|c|c|}
\hline Precursor & Calcination strategy & Nomenclature \\
\hline $\mathrm{Mn}(\mathrm{Ac})_{2}+\mathrm{Cu}\left(\mathrm{NO}_{3}\right)_{2}$ & Stagnant air calcination & $\mathrm{CuMn}_{\mathrm{SA} 1}$ \\
\hline $\mathrm{Mn}(\mathrm{Ac})_{2}+\mathrm{Cu}(\mathrm{Ac})_{2}$ & & $\mathrm{CuMn}_{\mathrm{SA} 2}$ \\
\hline $\mathrm{Mn}\left(\mathrm{NO}_{3}\right)_{2}+\mathrm{Cu}\left(\mathrm{NO}_{3}\right)_{2}$ & & $\mathrm{CuMn}_{\mathrm{SA} 3}$ \\
\hline $\mathrm{Mn}\left(\mathrm{NO}_{3}\right)_{2}+\mathrm{Cu}(\mathrm{Ac})_{2}$ & & $\mathrm{CuMn}_{\mathrm{SA} 4}$ \\
\hline $\mathrm{Mn}(\mathrm{Ac})_{2}+\mathrm{Cu}\left(\mathrm{NO}_{3}\right)_{2}$ & Flowing air calcination & $\mathrm{CuMn}_{\mathrm{FA} 1}$ \\
\hline $\mathrm{Mn}(\mathrm{Ac})_{2}+\mathrm{Cu}(\mathrm{Ac})_{2}$ & & $\mathrm{CuMn}_{\mathrm{FA} 2}$ \\
\hline $\mathrm{Mn}\left(\mathrm{NO}_{3}\right)_{2}+\mathrm{Cu}\left(\mathrm{NO}_{3}\right)_{2}$ & & $\mathrm{CuMn}_{\mathrm{FA} 3}$ \\
\hline $\mathrm{Mn}\left(\mathrm{NO}_{3}\right)_{2}+\mathrm{Cu}(\mathrm{Ac})_{2}$ & & $\mathrm{CuMn}_{\mathrm{FA} 4}$ \\
\hline $\mathrm{Mn}(\mathrm{Ac})_{2}+\mathrm{Cu}\left(\mathrm{NO}_{3}\right)_{2}$ & Reactive calcination & $\mathrm{CuMn}_{\mathrm{RC} 1}$ \\
\hline $\mathrm{Mn}(\mathrm{Ac})_{2}+\mathrm{Cu}(\mathrm{Ac})_{2}$ & & $\mathrm{CuMn}_{\mathrm{RC} 2}$ \\
\hline $\mathrm{Mn}\left(\mathrm{NO}_{3}\right)_{2}+\mathrm{Cu}\left(\mathrm{NO}_{3}\right)_{2}$ & & $\mathrm{CuMn}_{\mathrm{RC} 3}$ \\
\hline $\mathrm{Mn}\left(\mathrm{NO}_{3}\right)_{2}+\mathrm{Cu}(\mathrm{Ac})_{2}$ & & $\mathrm{CuMn}_{\mathrm{RC} 4}$ \\
\hline
\end{tabular}

\section{Characterization of catalysts}

The scanning electron micrograph (SEM) produced the high-resolution image of a catalyst by an electron beam, and the image of the catalyst is recorded on Zeiss EVO 18 (SEM) instrument. The magnification of images is $5000 \times$ and an accelerating voltage of $15 \mathrm{kV}$ was applied. It provides information about the average aggregate size, crystalline degree and the microstructures of the catalyst. The energy dispersive X-ray analyzer (EDX) provides information about elemental identification and performs a quantitative composition analysis of compounds present in the catalyst. The X-ray diffraction (XRD) analysis of the catalyst is carried out by using Rigaku D/MAX-2400 diffractometer with $\mathrm{Cu}-\mathrm{K} \alpha$ radiation at $40 \mathrm{kV}$ and $40 \mathrm{~mA}$. It is a fast analytical technique mainly applied for the measurement of phase identification, crystal orientation, crystallite size, unit cell dimensions and crystal defects, etc. The Fourier transform infrared spectroscopy (FTIR) provides information about the kind of materials present in a catalyst sample with their peak values. The measurement is done by the Shimadzu 8400 FTIR spectrometer in the range of $400-4000 \mathrm{~cm}^{-1}$. The Brunauer-Emmett-Teller analysis (BET) provides information about the specific surface area, pore volume and pore size of the catalyst. The isotherm is recorded by Micromeritics ASAP 2020 analyzer with the physical adsorption of $\mathrm{N}_{2}$ at the temperature of liquid nitrogen $\left(-196^{\circ} \mathrm{C}\right)$ with an average pressure range of $0.05-0.30 \mathrm{P} / \mathrm{P}_{\mathrm{o}}$.

\section{Experimental procedure}

The catalytic oxidation of $\mathrm{CO}$ over all the CuMnOx catalysts were carried out at atmospheric pressure in a fixed bed down-flow tubular reactor containing $100 \mathrm{mg}$ of catalyst which was diluted to $1 \mathrm{ml}$ of $\mathrm{Al}_{2} \mathrm{O}_{3}$ at a different temperature. The reactor was placed vertically in a split-open furnace in which the following reaction conditions were maintained: Catalyst particle size, $40-100$ mesh, using a lean mixture of $2.5 \% \mathrm{CO}(\mathrm{v} / \mathrm{v})$ in the air, maintaining the total flow rate at $60 \mathrm{ml} \mathrm{min}{ }^{-1}$. The details of the experimental apparatus setup are given in Fig. 1.

The flow rate of gasses was monitored with the help of digital gas flow meter. The air feed was made free of moisture and $\mathrm{CO}_{2}$ by passing it through $\mathrm{CaO}$ and $\mathrm{KOH}$ pellet drying towers. The catalytic experiments were carried out under steady-state conditions. Typically, the reactor was heated to the desired temperature with the help of a microprocessor-based temperature controller. A temperature control of $\pm 0.5^{\circ} \mathrm{C}$ was achieved. The gaseous products were analyzed by an online gas chromatograph (Nucon Series 5765) equipped with a methaniser, Porapack Q-column and FID detector for the concentration of $\mathrm{CO}$ and $\mathrm{CO}_{2}$. The catalytic activity was measured for the conversion of $\mathrm{CO}$ into 


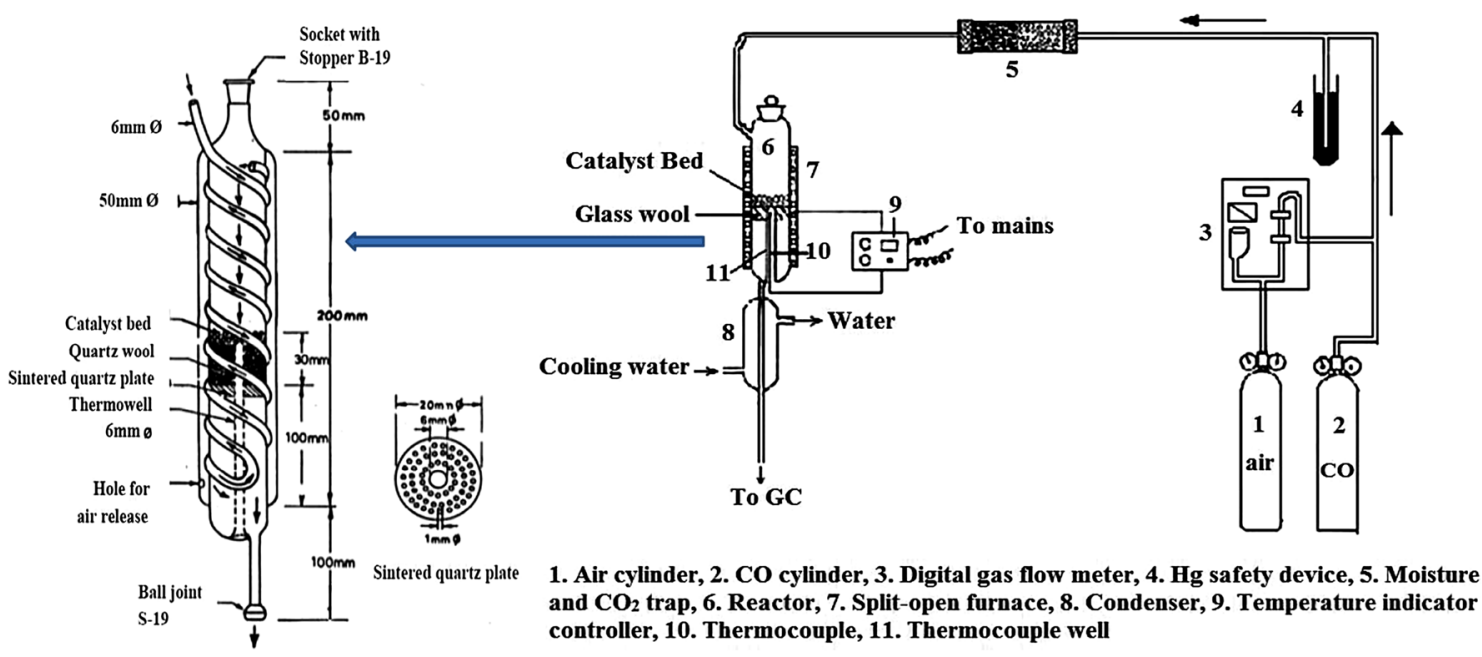

Fig. 1 Experimental apparatus setup for testing the catalyst

$\mathrm{CO}_{2}$. The conversion of $\mathrm{CO}$ at any instant was calculated on the basis of values of the concentration of $\mathrm{CO}\left(\mathrm{C}_{\mathrm{CO}}\right)_{\text {in }}$ in the feed and the concentration of $\mathrm{CO}_{2}\left(\mathrm{C}_{\mathrm{CO}}\right)_{\text {out }}$ in the product stream. The concentration of $\mathrm{CO}$ was proportional to the area of chromatogram $\mathrm{A}_{\mathrm{CO}}\left(\mathrm{A}_{\mathrm{CO}}\right)_{\text {in }}$ that at any instant was proportional to the area of the chromatogram of $\mathrm{CO}_{2}$ $\left(\mathrm{A}_{\mathrm{CO}}\right)_{\text {out }}$ formed.

\section{Blank experiment}

A blank experiment was carried out with $\mathrm{Al}_{2} \mathrm{O}_{3}$ only in place of catalyst. The bed temperature increased up to $300{ }^{\circ} \mathrm{C}$, but practically no oxidation of $\mathrm{CO}$ has observed under the experimental conditions. The blank test shows that the performance of reactor in the absence of catalyst for $\mathrm{CO}$ oxidation with the increase of temperature does not show any activity for $\mathrm{CO}$ oxidation. Thus, the catalytic effect of the reactor wall and the alumina use as diluents can be neglected within the experimental conditions.

\section{Catalyst characterization}

Characterization of all the CuMnOx catalysts prepared by various precursors in reactive calcination conditions was done by the following techniques and activity of the catalyst for $\mathrm{CO}$ oxidation was discussed below.

\section{Morphology analysis}

The scanning electron micrograph (SEM) instrument was used for the microstructure analysis of the optimized CuMnOx $\left(\mathrm{Cu}_{1} \mathrm{Mn}_{8}\right)$ catalysts. The SEM micrograph (Fig. 2) clearly shows the large differences in the microstructure and morphology of the CuMnOx catalysts formed by the different precursors. They all show granular particles between 0.30 and $10 \mu \mathrm{m}$ calculated by "Image J software" with varying degrees of agglomeration as mentioned in Table 2. The digital image processing (DIP) has only been applied to the SEM analysis of coarse aggregates and fine aggregates. The image analysis instrument may report distributions based on particle length as opposed to spherical equivalency, and they may build volume distributions based on shapes other than spheres. SEM technique (magnification ranging from $20 \times$ to approximately $30,000 \times$, spatial resolution of 50 to $100 \mathrm{~nm}$ ). The SEM has more than 300 times the depth of field of the light microscope. Magnification will increase if we reduce the size of the area scanned on the specimen. The SEM images of particles may be characterized by having higher intensity than the surrounding pixels. The particles can also be characterized by their form, such as roundness, elongation and orientation. The image $\mathbf{J}$ software provides the histogram for particle size distribution. The histogram of bulk samples shows that the maximum size distribution is in the range of $0.315-1.130 \mu \mathrm{m}[35,36]$. As shown in the SEM micrograph, the particles comprised grains of coarser, coarse, fine and finest sizes using $\mathrm{CuMn}_{\mathrm{RC} 4}, \mathrm{CuMn}_{\mathrm{RC} 3}$, $\mathrm{CuMn}_{\mathrm{RC} 2}$ and $\mathrm{CuMn}_{\mathrm{RC} 1}$ as catalysts, respectively. The SEM result was also in good agreement with XRD analysis. The average particle size of $\mathrm{CuMn}_{\mathrm{RC} 1}, \mathrm{CuMn}_{\mathrm{RC} 2}, \mathrm{CuMn}_{\mathrm{RC} 3}$ and $\mathrm{CuMn}_{\mathrm{RC} 4}$ catalyst was $0.315 \mu \mathrm{m}, 0.516 \mu \mathrm{m}, 0.891 \mu \mathrm{m}$ and $1.125 \mu \mathrm{m}$, respectively.

The particles of $\mathrm{CuMn}_{\mathrm{RC} 1}$ catalyst was least agglomerated, highly porous, uniformly distributed, and had a higher surface area. The choice of precursors in the CuMnOx catalysts lead to the change of surface distribution of $\mathrm{Cu}$, $\mathrm{Mn}$ and $\mathrm{O}$ elements, which might be related to the $\mathrm{CO}$ oxidation [36-38]. Thus, the different precursors used in the 

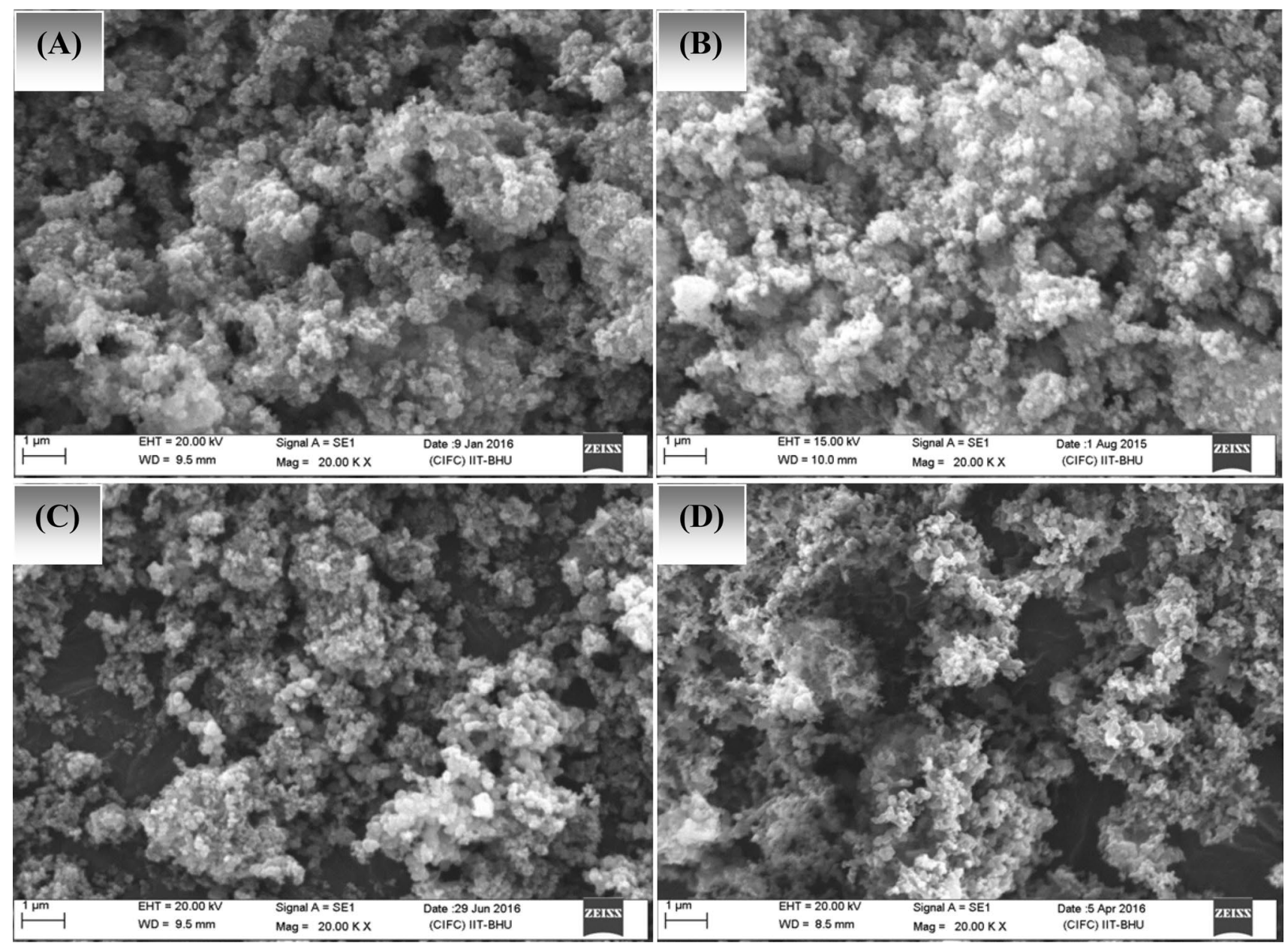

Fig. 2 SEM image of $\mathbf{a} \mathrm{CuMn}_{\mathrm{RC} 4}, \mathbf{b} \mathrm{CuMn}_{\mathrm{RC} 3}, \mathbf{c} \mathrm{CuMn}_{\mathrm{RC} 2}$ and $\mathbf{d} \mathrm{CuMn}_{\mathrm{RC} 1}$

Table 2 Particle size of $\mathrm{CuMn}_{\mathrm{RC}}$ catalysts

\begin{tabular}{ll}
\hline Catalyst & Particle size $(\mu \mathrm{m})$ \\
\hline $\mathrm{CuMn}_{\mathrm{RC} 1}$ & 0.315 \\
$\mathrm{CuMn}_{\mathrm{RC} 2}$ & 0.516 \\
$\mathrm{CuMn}_{\mathrm{RC} 3}$ & 0.891 \\
$\mathrm{CuMn}_{\mathrm{RC} 4}$ & 1.125 \\
\hline
\end{tabular}

preparation of $\mathrm{CuMnOx}\left(\mathrm{Cu}_{1} \mathrm{Mn}_{8}\right)$ catalysts in the present study considerably affect the particle size as well as the morphology of resulting catalysts.

The synergetic effect of $\mathrm{CuMn}_{\mathrm{RC} 1}$ catalyst was highly dependent upon the catalyst composition and the nature of oxidized compounds. All the catalysts have different morphologies, indicating that the types of precursors used in the preparation of catalysts have a great influence on the catalytic activity. The mixing of $\left\{\mathrm{Mn}(\mathrm{Ac})_{2}+\mathrm{Cu}\left(\mathrm{NO}_{3}\right)_{2}\right\}$ and precipitation by $\mathrm{KMnO}_{4}$ solution was more efficient in improving the catalytic behavior of $\mathrm{CuMnOx}$ catalysts for $\mathrm{CO}$ oxidation.

\section{Elemental analysis}

To verify the atomic ratio of $\mathrm{Cu}$ to $\mathrm{Mn}$ in the $\mathrm{CuMnOx}$ catalysts, scanning electron microscopy (SEM) with energy dispersive X-Ray analysis (SEM-EDX) techniques were performed in a large scanning range randomly for the samples $\mathrm{CuMn}_{\mathrm{RC} 4}, \mathrm{CuMn}_{\mathrm{RC} 3}, \mathrm{CuMn}_{\mathrm{RC} 2}$ and $\mathrm{CuMn}_{\mathrm{RC} 1}$, respectively. The elemental concentration distribution of the catalyst granules was determined using Isis 300 software [39]. The result of SEM-EDX analysis has shown that all the catalyst samples were pure due to the presence of their relevant element peaks only. It was provided in an EDX mapping of $\mathrm{Cu}$ and $\mathrm{Mn}$ instead on different cross-sectioned marks of CuMnOx catalysts granules to determine the concentration of different elements located at different cross-sections on the catalysts' granular surfaces as shown in the Fig. 3. Table 3 represents the relative atomic abundance of $\mathrm{Cu}, \mathrm{Mn}$ and $\mathrm{O}$ species present in the surface layers of $\mathrm{CuMnOx}$ catalysts. The presence of $\mathrm{Cu}, \mathrm{Mn}$ and $\mathrm{O}$ peaks on the surface of $\mathrm{CuM}$ nOx catalysts can be clearly detected. 
The surface atomic ratio of the catalysts prepared with different precursors was compiled in Table 3. The atomic ratio and weight ratio of $\mathrm{Cu} / \mathrm{Mn}$ in the $\mathrm{CuMn}_{\mathrm{RC} 1}$ catalyst was approximately 0.155 and 0.171 , respectively. The molar ratio of $\mathrm{Cu} / \mathrm{Mn}$ in all the catalyst samples using co-precipitation method was approximately 0.187 and it was very close to the actual dosage of $\mathrm{Cu}$ and $\mathrm{Mn}$ percentage present in the precursors.

The abundant surface oxygen atoms of the $\mathrm{CuMn}_{\mathrm{RC}}$ catalyst can react with the absorbed $\mathrm{CO}$ and thus lead to better catalytic activity in the Mars-van Krevelen type mechanism
(MvK) which was frequently suggested for the metal oxides [40]. It was clear from the Table 3 and Fig. 3 that the atomic percentage and weight percentage of Mn was also higher in comparison to $\mathrm{Cu}$ and $\mathrm{O}$. A calcination strategy of $\mathrm{CuMn} \mathrm{RC}_{\mathrm{RC}}$ catalyst has highly influenced the elemental distribution of different elements present on the catalysts' surfaces. The choice of precursors can lead to the change of surface distribution of $\mathrm{Cu}, \mathrm{Mn}$ and $\mathrm{O}$ elements, which might be related to the $\mathrm{CO}$ oxidation on the $\mathrm{CuMn}_{\mathrm{RC}}$ catalysts. The presence of a small amount of oxygen in the surface layer of $\mathrm{CuMn}_{\mathrm{RC} 1}$ catalyst causes the number of active sites present on the
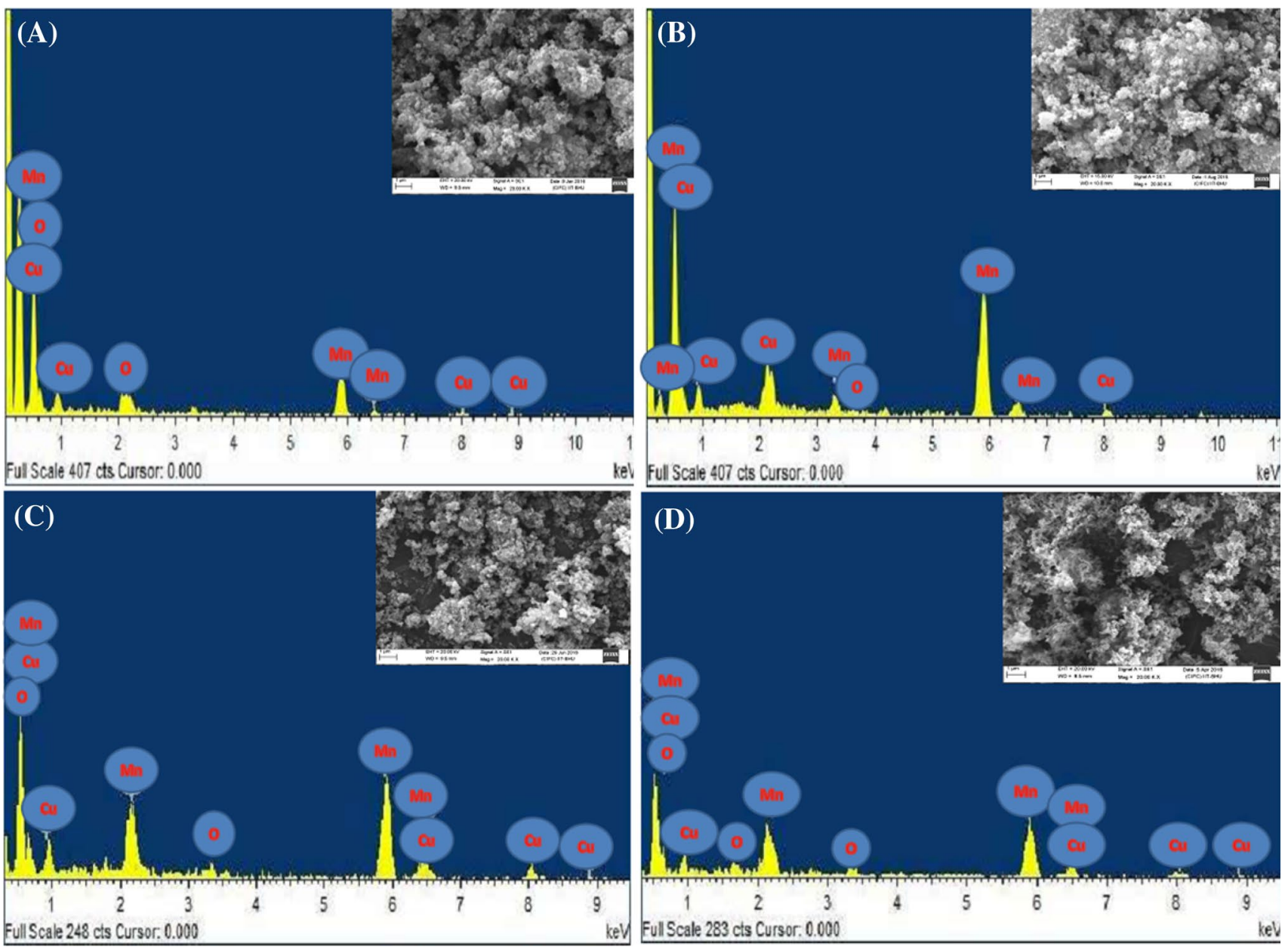

Fig. 3 SEM-EDX image of $\mathbf{a} \mathrm{CuMn}_{\mathrm{RC} 4}, \mathbf{b} \mathrm{CuMn}_{\mathrm{RC} 3}, \mathbf{c} \mathrm{CuMn}_{\mathrm{RC} 2}$ and $\mathbf{d} \mathrm{CuMn}_{\mathrm{RC} 1}$

Table 3 The atomic and weight ratios of $\mathrm{Cu}, \mathrm{Mn}$ and $\mathrm{O}$ in CuMnOx catalyst by EDX analysis

\begin{tabular}{|c|c|c|c|c|c|c|c|c|}
\hline \multirow[t]{2}{*}{ Catalyst } & \multicolumn{4}{|c|}{ Atomic percentage $(\%)$} & \multicolumn{4}{|c|}{ Weight percentage (\%) } \\
\hline & $\mathrm{Cu}$ & $\mathrm{Mn}$ & $\mathrm{O}$ & $\mathrm{Cu} / \mathrm{Mn}$ & $\mathrm{Cu}$ & $\mathrm{Mn}$ & $\mathrm{O}$ & $\mathrm{Cu} / \mathrm{Mn}$ \\
\hline $\mathrm{CuMn}_{\mathrm{RC} 1}$ & 12.65 & 81.54 & 5.81 & 0.155 & 13.81 & 80.35 & 5.84 & 0.171 \\
\hline $\mathrm{CuMn}_{\mathrm{RC} 2}$ & 13.79 & 78.15 & 8.06 & 0.176 & 13.75 & 78.56 & 7.69 & 0.175 \\
\hline $\mathrm{CuMn}_{\mathrm{RC} 3}$ & 11.41 & 73.81 & 14.78 & 0.154 & 11.85 & 73.95 & 14.20 & 0.160 \\
\hline $\mathrm{CuMn}_{\mathrm{RC} 4}$ & 9.65 & 71.25 & 19.10 & 0.135 & 9.89 & 71.46 & 18.65 & 0.138 \\
\hline
\end{tabular}


catalyst surface to increase. The successful redox reactions in the presence of lattice oxygen of $\mathrm{CuMnOx}$ catalysts and its charge (hole or electron) transfer ability between $\mathrm{Cu}^{+}$and $\mathrm{Cu}^{2+}$ [39]. The surface property of the catalyst was highly influenced by the calcination process; the crystallinity was lost with the increase of calcination temperature, with gradual transformation to amorphous $\mathrm{CuMnOx}$ phase.

\section{Phase identification and cell dimensions}

The phase identification and cell dimensions of $\mathrm{CuMnOx}$ catalysts prepared in reactive calcination conditions were done by the X-ray powder diffraction (XRD) technique. The crystalline size and coordinate dimensions present on the surface layer of the catalysts were identified. The mean crystallite size $(d)$ of the catalyst was calculated from the line broadening of the most intense reflection using the Scherrer Equation $(d=0.89 \lambda / \beta \cos \theta)$. Where $d$ was the mean crystallite diameter, 0.89 was the Scherrer constant, 1 is the X-ray wave length (1.54056 $\AA$ ), and $b$ was the effective line width of the observed X-ray reflection. It provides information about the structure, phase, crystal orientation, lattice parameters, crystallite size, strain and crystal defects, etc., [32]. XRD patterns of the CuMnOx catalyst produced by reactive calcination of the various precursors $\left(\mathrm{CuMn}_{\mathrm{RC} 1}, \mathrm{CuMn}_{\mathrm{RC} 2}\right.$, $\mathrm{CuMn}_{\mathrm{RC} 3}$ and $\mathrm{CuMn}_{\mathrm{RC} 4}$ ) are displayed in Fig. 4. XRD pattern of the $\mathrm{CuMn}_{\mathrm{RC} 1}$ catalyst has shown that the diffraction peak at $2 \theta$ of 32.96 corresponds to its lattice plane (112) end-centered cubic $\mathrm{Cu}_{1} \mathrm{Mn}_{8} \mathrm{O}_{2}$ (PDF-75-1010 JCPDS file). The crystallite size of the catalyst was $3.90 \mathrm{~nm}$. In reactive calcination of $\mathrm{CuMn}_{\mathrm{RC} 2}$ catalyst was shown that the diffraction peak at $2 \theta$ of 33.60 corresponds to its lattice plane (110) of face-centered cubic $\mathrm{Cu}_{0.2} \mathrm{Mn}_{1.8} \mathrm{O}_{4}$ (PDF-72-1254 JCPDS file). The crystallite size of the catalyst was $4.215 \mathrm{~nm}$.

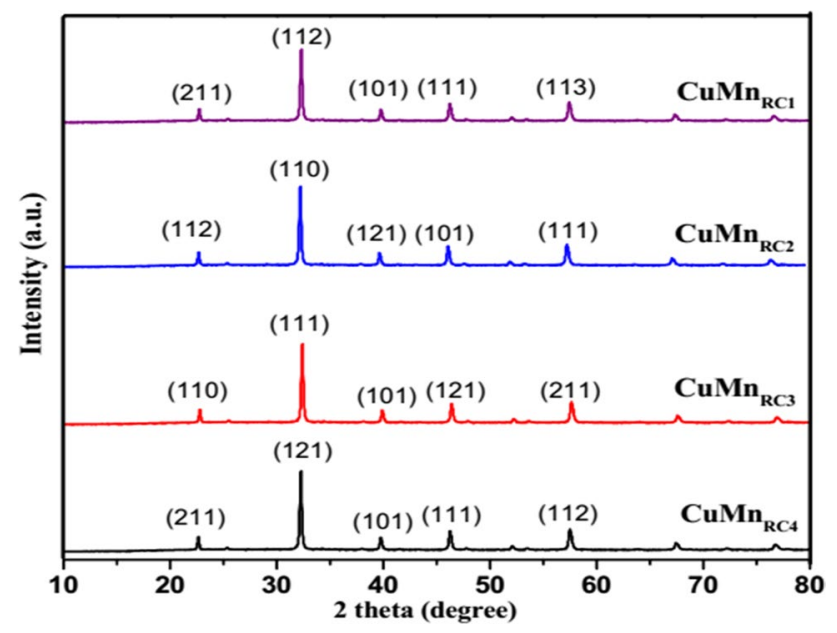

Fig. 4 XRD analysis of a $\mathrm{CuMn}_{\mathrm{RC} 1}, \mathbf{b} \mathrm{CuMn}_{\mathrm{RC} 2}, \mathbf{c} \mathrm{CuMn}_{\mathrm{RC} 3}$ and $\mathbf{d}$ $\mathrm{CuMn}_{\mathrm{RC} 4}$
The XRD pattern of the $\mathrm{CuMn}_{\mathrm{RC} 3}$ catalyst has shown that the diffraction peak at $2 \theta$ of 32.43 corresponds to its lattice plane (111) of cubic-centered $\mathrm{Cu}_{1} \mathrm{Mn}_{6.8} \mathrm{O}_{4}$ (PDF-84-0543 JCPDS file). The crystallite size of the catalyst was $5.61 \mathrm{~nm}$. XRD pattern of the $\mathrm{CuMn}_{\mathrm{RC} 4}$ catalyst has shown that the diffraction peak at $2 \theta$ of 33.23 corresponds to its lattice plane (121) body-centered tetragonal $\mathrm{Cu}_{0.2} \mathrm{Mn}_{1.8} \mathrm{O}_{2}$ (PDF-78-1012 JCPDS file). The crystallite size of the catalyst was $7.90 \mathrm{~nm}$. The broader peak in $\mathrm{CuMn}_{\mathrm{RC} 1}$ has indicated that the relatively amorphous nature of the catalyst and their structure, phase, and crystallite size are also discussed in Table 4.

After XRD analysis, we have confirmed that the crystallite size of $\mathrm{CuMn}_{\mathrm{RC} 1}$ is lower than the $\mathrm{CuMn}_{\mathrm{RC} 2}, \mathrm{CuMn}_{\mathrm{RC} 3}$ and $\mathrm{CuMn}_{\mathrm{RC} 4}$ catalysts. The structure, phase and crystallite size of $\mathrm{CuMn}_{\mathrm{RC}}$ catalysts have been represented in Table 4 . The crystallite size of the particles present in a catalyst surface obtained by RC conditions was as follows: $\mathrm{CuMn}_{\mathrm{RC} 4}>\mathrm{CuMn}_{\mathrm{RC} 3}>\mathrm{CuMn}_{\mathrm{RC} 2}>\mathrm{CuMn}_{\mathrm{RC} 1}$. It was quite apparent that the crystallite size of $\mathrm{CuMn}_{\mathrm{RC} 1}$ catalyst exhibited the smallest size $(3.90 \mathrm{~nm})$ in comparison to $\mathrm{CuMn}_{\mathrm{RC} 2}$ $(4.21 \mathrm{~nm}), \mathrm{CuMn}_{\mathrm{RC} 3}(5.61 \mathrm{~nm})$ and $\mathrm{CuMn}_{\mathrm{RC} 4}(7.90 \mathrm{~nm})$. From Table 4 and Fig. 4, we have confirmed that the particles present in $\mathrm{CuMn}_{\mathrm{RC} 1}$ catalyst were mostly in crystalline form, and producing narrow size high-intensity diffraction lines, as compared to the other catalysts. The refinement of the XRD pattern of $\mathrm{CuMn}_{\mathrm{RC}}$ sample has shown that there will be no impurity phases present in the catalysts.

\section{Identification of the materials present in a catalyst}

The identification of the metal-oxygen bonds present in the catalyst was done by the Fourier transform infrared spectroscopy (FTIR) analysis. The different peaks show various types of chemical groups present on the catalyst surfaces. The FTIR transmission spectrum of the $\mathrm{CuMn}_{\mathrm{RC} 1}, \mathrm{CuMn}_{\mathrm{RC} 2}$, $\mathrm{CuMn}_{\mathrm{RC} 3}$ and $\mathrm{CuMn}_{\mathrm{RC} 4}$ catalysts prepared by reactive calcination (RC) conditions is shown in the Fig. 5. In the $\mathrm{CuMn}_{\mathrm{RC} 1}$ catalyst at the transmittance conditions, there were total three peaks we obtained, the IR band $\left(1640 \mathrm{~cm}^{-1}\right)$ has shown the presence of $\mathrm{MnO}_{2}$ group, $\left(3490 \mathrm{~cm}^{-1}\right) \mathrm{CuO}$ group and $\left(1180 \mathrm{~cm}^{-1}\right) \mathrm{H}-\mathrm{OH}$ group. In the $\mathrm{CuMn}_{\mathrm{RC} 2}$ catalyst at the transmittance conditions, there were total five peaks we obtained, the $\mathrm{MnO}_{2}$ vibration mode was observed

Table $4 \mathrm{XRD}$ analysis of $\mathrm{CuMn}_{\mathrm{RC}}$ catalysts

\begin{tabular}{llll}
\hline Catalyst & Structure & Phase & $\begin{array}{l}\text { Crystallite } \\
\text { size (nm) }\end{array}$ \\
\hline $\mathrm{CuMn}_{\mathrm{RC} 1}$ & End-centered cubic & $\mathrm{Cu}_{1} \mathrm{Mn}_{8} \mathrm{O}_{2}$ & 3.90 \\
$\mathrm{CuMn}_{\mathrm{RC} 2}$ & Face-centered cubic & $\mathrm{Cu}_{0.2} \mathrm{Mn}_{1.8} \mathrm{O}_{4}$ & 4.21 \\
$\mathrm{CuMn}_{\mathrm{RC} 3}$ & Cubic-centered & $\mathrm{Cu}_{1} \mathrm{Mn}_{6.8} \mathrm{O}_{4}$ & 5.61 \\
$\mathrm{CuMn}_{\mathrm{RC} 4}$ & Body-centered tetragonal & $\mathrm{Cu}_{0.2} \mathrm{Mn}_{1 \cdot 8} \mathrm{O}_{2}$ & 7.90 \\
\hline
\end{tabular}



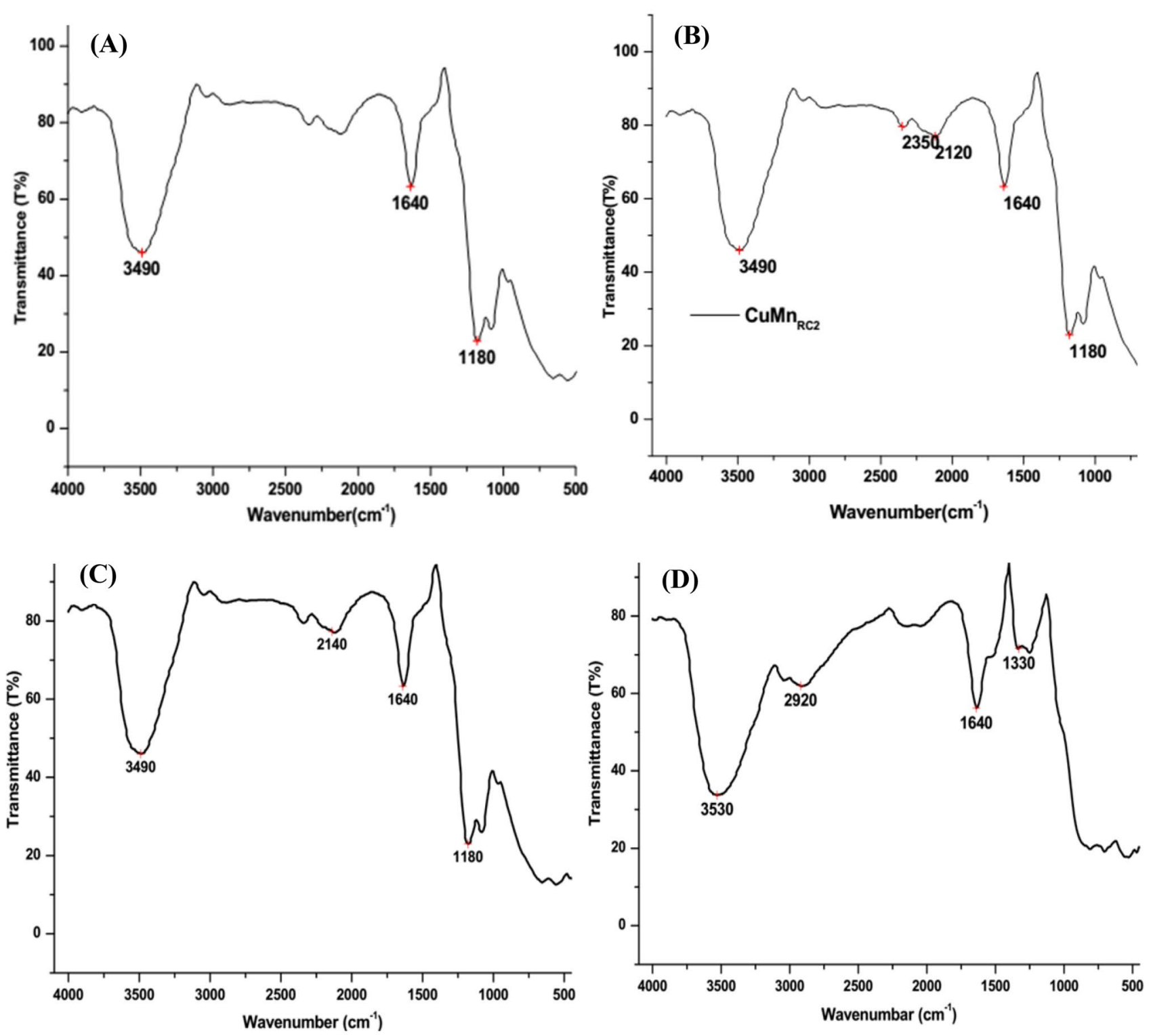

Fig. 5 FT-IR analysis of $\mathbf{a} \mathrm{CuMn}_{\mathrm{RC} 1}, \mathbf{b} \mathrm{CuMn}_{\mathrm{RC} 2}, \mathbf{c} \mathrm{CuMn}_{\mathrm{RC} 3}$ and $\mathbf{d} \mathrm{CuMn}_{\mathrm{RC} 4}$

at $\left(1640 \mathrm{~cm}^{-1}\right),\left(3490 \mathrm{~cm}^{-1}\right)$ was assigned to $\mathrm{CuO}$ group, $\left(2350 \mathrm{~cm}^{-1}\right.$ and $\left.1180 \mathrm{~cm}^{-1}\right) \mathrm{H}-\mathrm{OH}$ group and $\left(2120 \mathrm{~cm}^{-1}\right)$ $\mathrm{C}=\mathrm{O}$ group.

In the $\mathrm{CuMn}_{\mathrm{RC} 3}$ catalyst at the transmittance conditions, there were a total of four peaks that we obtained, the IR band $\left(1640 \mathrm{~cm}^{-1}\right)$ has shown the presence of $\mathrm{MnO}_{2}$ group, (3490 $\left.\mathrm{cm}^{-1}\right) \mathrm{CuO}$ group, $\left(1180 \mathrm{~cm}^{-1}\right) \mathrm{H}-\mathrm{OH}$ group and $\left(2140 \mathrm{~cm}^{-1}\right) \mathrm{CO}_{3}{ }^{2-}$ group. In the $\mathrm{CuMn}_{\mathrm{RC} 4}$ catalyst at the transmittance conditions, there were a total of four peaks that we obtained, the $\mathrm{MnO}_{2}$ vibration mode was observed at $\left(1640 \mathrm{~cm}^{-1}\right)$ due to the stretching of $\mathrm{Mn}-\mathrm{O}$ bond and transmission spectra at $\left(3530 \mathrm{~cm}^{-1}\right)$ was assigned to $\mathrm{CuO}$ group. The other phases like $\mathrm{CO}_{3}{ }^{2-}$ and $\mathrm{C}=\mathrm{O}$ were present at $\left(1330 \mathrm{~cm}^{-1}\right)$ and $\left(2920 \mathrm{~cm}^{-1}\right)$, respectively. The spectra of impurities decrease in the following order: $\mathrm{CuMn}_{\mathrm{RC} 4}>\mathrm{CuMn}_{\mathrm{RC} 3}>\mathrm{CuMn}_{\mathrm{RC} 2}>\mathrm{CuMn}_{\mathrm{RC} 1}$. The best result we can get from the FTIR analysis was that the $\mathrm{CuMn}_{\mathrm{RC} 1}$ catalyst has the highest purity as compared to the other catalysts; therefore, we get the best activity results for $\mathrm{CO}$ oxidation.

\section{Identification and quantification of elements}

The surface valence state and chemical concentration of the catalysts were investigated by the X-ray photoelectron spectroscopy (XPS) analysis. The XPS analysis that was mainly used to understand the physical and chemical 
changes of the catalyst with exposure to gaseous molecules under the different thermal conditions has been examined. Although, it can be proposed that the high binding energy was preferable for the CO oxidation. The XPS spectra in the $\mathrm{Cu}(2 \mathrm{p}), \mathrm{Mn}(2 \mathrm{p})$ and $\mathrm{O}(1 \mathrm{~s})$ regions are shown in the figures. The prominent peak of $\mathrm{Cu}(2 \mathrm{p})$ level in $\mathrm{CuMn}_{\mathrm{RCl}}$, $\mathrm{CuMn}_{\mathrm{RC} 2}, \mathrm{CuMn}_{\mathrm{RC} 3}$ and $\mathrm{CuMn}_{\mathrm{RC} 4}$ catalyst was deconvoluted into five to six peaks centered as shown in the Fig. 6. By performing peak fitting deconvolution, the main $\mathrm{Cu}(2 \mathrm{p})$ in all the catalyst samples was found to be $\mathrm{Cu}$ (II) oxide form. The binding energy of $\mathrm{Cu}(2 \mathrm{p})$ in $\mathrm{CuMn}_{\mathrm{RC} 1}$ catalyst was $954.033 \mathrm{eV}, 956.600 \mathrm{eV}, 960.844 \mathrm{eV}, 962.22 \mathrm{eV}$, $964.718 \mathrm{eV}$ and $967.32 \mathrm{eV}$, respectively, and the highest binding energy peak of $\mathrm{Cu}(2 \mathrm{p})$ in $\mathrm{CuMn}_{\mathrm{RC} 1}$ catalyst was obtained at $964.718 \mathrm{eV}$. The binding energy of $\mathrm{Cu}(2 \mathrm{p})$ in $\mathrm{CuMn}_{\mathrm{RC} 2}$ catalyst was $954.019 \mathrm{eV}, 956.512 \mathrm{eV}, 960.714 \mathrm{eV}$, $962.102 \mathrm{eV}, 964.523$ and $967.149 \mathrm{eV}$, respectively, and the highest binding energy peak of $\mathrm{Cu}(2 \mathrm{p})$ in $\mathrm{CuMn}_{\mathrm{RC} 2}$ catalyst was obtained at $964.523 \mathrm{eV}$.
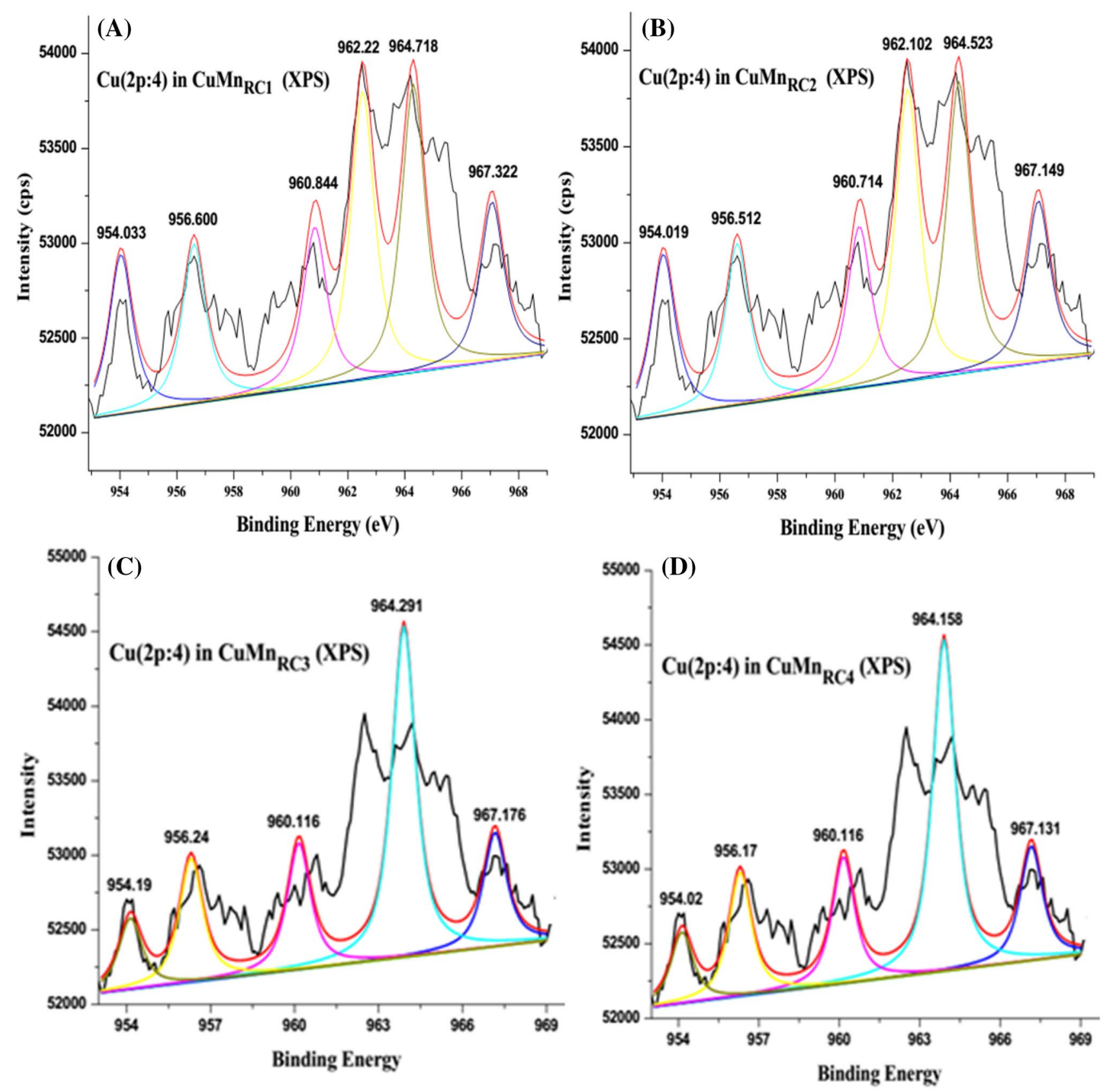

Fig. 6 XPS analysis of $\mathrm{Cu}(2 \mathrm{p})$ in a $\mathrm{CuMn}_{\mathrm{RC} 1}, \mathbf{b} \mathrm{CuMn}_{\mathrm{RC} 2}, \mathbf{c} \mathrm{CuMn}_{\mathrm{RC} 3}$ and $\mathbf{d} \mathrm{CuMn}_{\mathrm{RC} 4}$ 
The binding energy of $\mathrm{Cu}(2 \mathrm{p})$ in $\mathrm{CuMn}_{\mathrm{RC} 3}$ catalyst was $954.19 \mathrm{eV}, 956.24 \mathrm{eV}, 960.116 \mathrm{eV}, 964.291 \mathrm{eV}$ and $967.176 \mathrm{eV}$, respectively, and the highest binding energy peak of $\mathrm{Cu}(2 \mathrm{p})$ in $\mathrm{CuMn}_{\mathrm{RC} 3}$ catalyst was obtained at $964.291 \mathrm{eV}$. The binding energy of $\mathrm{Cu}(2 \mathrm{p})$ in $\mathrm{CuMn}_{\mathrm{RC} 4}$ catalyst was $954.02 \mathrm{eV}, 956.17 \mathrm{eV}, 960.116 \mathrm{eV}, 964.158 \mathrm{eV}$ and $967.131 \mathrm{eV}$, respectively, and the highest binding energy peak of $\mathrm{Cu}(2 \mathrm{p})$ in $\mathrm{CuMn}_{\mathrm{RC} 4}$ catalyst was obtained at $964.158 \mathrm{eV}$. The highest binding energy peak of $\mathrm{Cu}(2 \mathrm{p})$ in $\mathrm{CuMn}_{\mathrm{RC} 1}, \mathrm{CuMn}_{\mathrm{RC} 2}, \mathrm{CuMn}_{\mathrm{RC} 3}$ and $\mathrm{CuMn}_{\mathrm{RC} 4}$ catalyst was $964.718 \mathrm{eV}, 964.523 \mathrm{eV}, 964.291 \mathrm{eV}$ and $964.158 \mathrm{eV}$, respectively. It was clear from the Table 5 and Fig. 7 that the binding energy of $\mathrm{Cu}(2 \mathrm{p})$ in $\mathrm{CuMn}_{\mathrm{RC} C}$ catalyst was highest as comparison to other catalysts. The prominent peak of $\mathrm{Mn}(2 \mathrm{p})$ level in CuMnOx catalyst was deconvoluted into double peak and it is represented in the Fig. 7.

By performing peak fitting deconvolution of the main $\mathrm{Mn}(2 \mathrm{p})$ in all the catalyst samples, three main components including $\mathrm{Mn}^{4+}, \mathrm{Mn}^{3+}$ and satellite can be found. The difference between the binding energy values of $\mathrm{Mn}^{4+}$ and $\mathrm{Mn}^{3+}$ ions was small. The binding energy of $\mathrm{Mn}(2 \mathrm{p})$ in $\mathrm{CuMn}_{\mathrm{RCl}}$, $\mathrm{CuMn}_{\mathrm{RC} 2}, \mathrm{CuMn}_{\mathrm{RC} 3}$ and $\mathrm{CuMn}_{\mathrm{RC} 4}$ catalyst at reactive calcination condition was $(643.212 \mathrm{eV}$ and $655.361 \mathrm{eV})$, (643.189 $\mathrm{eV}$ and $655.349 \mathrm{eV}),(643.172$ and $655.295 \mathrm{eV})$ and $(643.151 \mathrm{eV}$ and $655.285 \mathrm{eV})$, respectively, and it will be associated with the presence of $\mathrm{Mn}^{3+}, \mathrm{Mn}^{4+}$ and satellite in all the samples. The highest binding energy peak of $\mathrm{Mn}(2 \mathrm{p})$ in $\mathrm{CuMn}_{\mathrm{RC} 1}, \mathrm{CuMn}_{\mathrm{RC} 2}, \mathrm{CuMn}_{\mathrm{RC} 3}$ and $\mathrm{CuMn}_{\mathrm{RC} 4}$ catalyst was $655.361 \mathrm{eV}, 655.349 \mathrm{eV}, 655.295 \mathrm{eV}$ and $655.285 \mathrm{eV}$, respectively. The broad $\mathrm{Mn}^{4+}$ peak present in $\mathrm{CuMn}_{\mathrm{RC} 1}$ catalyst was higher than $\mathrm{CuMn}_{\mathrm{RC} 2}, \mathrm{CuMn}_{\mathrm{RC} 3}$ and $\mathrm{CuMn}_{\mathrm{RC} 4}$ catalyst. Finally, we confirmed that the binding energy of $\mathrm{Mn}(2 \mathrm{p})$ present in $\mathrm{CuMn}_{\mathrm{RC} 1}$ catalyst was highest as compared to other catalyst samples.

In present study, the oxygen with the binding energy of $529.58 \mathrm{eV}$ was the main form and could be assigned to the chemisorbed oxygen (Oa). The presence of lattice oxygen was very small in $\mathrm{CuMn}_{\mathrm{RC} 1}$ catalyst. The binding energy of $\mathrm{O}(1 \mathrm{~s})$ in $\mathrm{CuMn}_{\mathrm{RC} 1}, \mathrm{CuMn}_{\mathrm{RC} 2}, \mathrm{CuMn}_{\mathrm{RC} 3}$ and

Table 5 Binding energy and chemical state of $\mathrm{CuMn}_{\mathrm{RC}}$ catalysts

\begin{tabular}{llll}
\hline Sample & Elements & & \\
\cline { 2 - 4 } & $\mathrm{Cu}$ & $\mathrm{Mn}$ & $\mathrm{O}$ \\
\hline $\mathrm{CuMn}_{\mathrm{RC} 1}$ & $\mathrm{Cu}$ (II) Oxide & $\mathrm{Mn}_{2} \mathrm{O}_{3}$ & $\mathrm{C}-\mathrm{O}$ \\
& $964.718 \mathrm{eV}$ & $655.361 \mathrm{eV}$ & $529.84 \mathrm{eV}$ \\
$\mathrm{CuMn}_{\mathrm{RC} 2}$ & $\mathrm{Cu}$ (II) Oxide & $\mathrm{Mn}_{2} \mathrm{O}_{3}$ & $\mathrm{C}-\mathrm{O}$ \\
& $964.523 \mathrm{eV}$ & $655.349 \mathrm{eV}$ & $529.41 \mathrm{eV}$ \\
$\mathrm{CuMn}_{\mathrm{RC} 3}$ & $\mathrm{Cu}$ (II) Oxide & $\mathrm{Mn}_{2} \mathrm{O}_{3}$ & $\mathrm{C}-\mathrm{O}$ \\
& $964.291 \mathrm{eV}$ & $655.295 \mathrm{eV}$ & $529.24 \mathrm{eV}$ \\
$\mathrm{CuMn}_{\mathrm{RC} 4}$ & $\mathrm{Cu}(\mathrm{II}) \mathrm{Oxide}$ & $\mathrm{Mn}_{2} \mathrm{O}_{3}$ & $\mathrm{C}-\mathrm{O}$ \\
& $964.158 \mathrm{eV}$ & $655.285 \mathrm{eV}$ & $529.08 \mathrm{eV}$ \\
\hline
\end{tabular}

$\mathrm{CuMn}_{\mathrm{RC} 4}$ catalyst was $529.84 \mathrm{eV}, 529.41 \mathrm{eV}, 529.24 \mathrm{eV}$ and $529.08 \mathrm{eV}$, respectively. The chemical state of $\mathrm{Cu}$, $\mathrm{Mn}$ and $\mathrm{O}$ in $\mathrm{CuMn}{ }_{\mathrm{RC}}$ catalyst was $\mathrm{Cu}(\mathrm{II})$ Oxide, $\mathrm{Mn}_{2} \mathrm{O}_{3}$ and $\mathrm{C}-\mathrm{O}$ form and it was represented in Table 5. One of noticeable facts was that the amount of oxygen is present less in reactive calcined prepared $\mathrm{CuMn}_{\mathrm{RC} 1}$ catalyst as compared to the $\mathrm{CuMn}_{\mathrm{RC} 2}, \mathrm{CuMn}_{\mathrm{RC} 3}$ and $\mathrm{CuMn}_{\mathrm{RC} 4}$ catalysts, due to an absence of lattice oxygen which creates oxygen vacancies for $\mathrm{CO}$ oxidation. The content order of $\mathrm{O}_{\mathrm{a}} /\left(\mathrm{O}_{\mathrm{a}}+\mathrm{O}_{1}\right)$ ratio was shown as follows: $\mathrm{CuMn}_{\mathrm{RC} 1}>\mathrm{CuMn}_{\mathrm{RC} 2}>\mathrm{CuMn}_{\mathrm{RC} 3}>\mathrm{CuMn}_{\mathrm{RC} 4}$. The presence of higher oxidation state phases could be the result of a greater degree of surface interaction between the easily oxidisable manganese phase and highly reducible copper phase [41]. The high amount of surface chemisorbed oxygen (most active oxygen) was more preferable for enhancing the catalytic activity for $\mathrm{CO}$ oxidation.

\section{Surface area measurement of catalyst}

BET surface area of CuMnOx catalyst was prepared by the co-precipitation method with a novel route of reactive calcination was much superior to the other calcination routes like flowing air and stagnant air. Clearly, the textural property of $\mathrm{CuMn}_{\mathrm{RC} 1}$ catalyst was much superior to the $\mathrm{CuMn}_{\mathrm{RC} 2}$, $\mathrm{CuMn}_{\mathrm{RC} 3}$ and $\mathrm{CuMn}_{\mathrm{RC} 4}$ catalysts. It can be visualized from the Table 6 and Fig. 8 that the pore volume and pore size of $\mathrm{CuMn}_{\mathrm{RC} 1}$ catalyst in reactive calcined was much higher than the other catalyst samples. The isotherm gave useful information on the mesopores' structure through its hysteresis loop. The catalyst samples exhibited hysteresis loop, which indicated that the pores were exhibiting geometries of mesopores. The surface area and pore volume isotherms of $\mathrm{CuMn}_{\mathrm{RC}}$ catalyst are shown in the Fig. 8. The existence of hysteresis loop at a relative pressure $\left(\mathrm{P} / \mathrm{P}_{0}\right)$ of $0.8-1.0$ indicates the porosity arising from the non-crystalline intraaggregate voids and spaces formed by inter-particle contacts.

The $\mathrm{N}_{2}$ adsorption-desorption isotherms and their porous textural parameters, such as specific surface area $\left(S_{\mathrm{BET}}\right)$ and pore volume $\left(V_{\text {total }}\right)$ are also listed in Table 6 . The surface area of $\mathrm{CuMn}_{\mathrm{RC} 1}, \mathrm{CuMn}_{\mathrm{RC} 2}, \mathrm{CuMn}_{\mathrm{RC} 3}$ and $\mathrm{CuMn}_{\mathrm{RC} 4}$ catalyst was $118.45,107.81,95.28$ and $88.57 \mathrm{~m}^{2} / \mathrm{g}$, respectively. These data clearly indicate that the precursors have also a high efficacy for the low temperature $\mathrm{CO}$ oxidation. In the mesopores, molecules from a liquid-like adsorbed phase having a meniscus of which curvature was associated with the Kelvin equation, providing the pore size distribution calculation. Specific surface area and total pore volume were two major factors which can influence the catalytic activity for $\mathrm{CO}$ oxidation.

The catalyst surface areas of similar magnitude regardless of the preparation atmosphere; however, there was a 

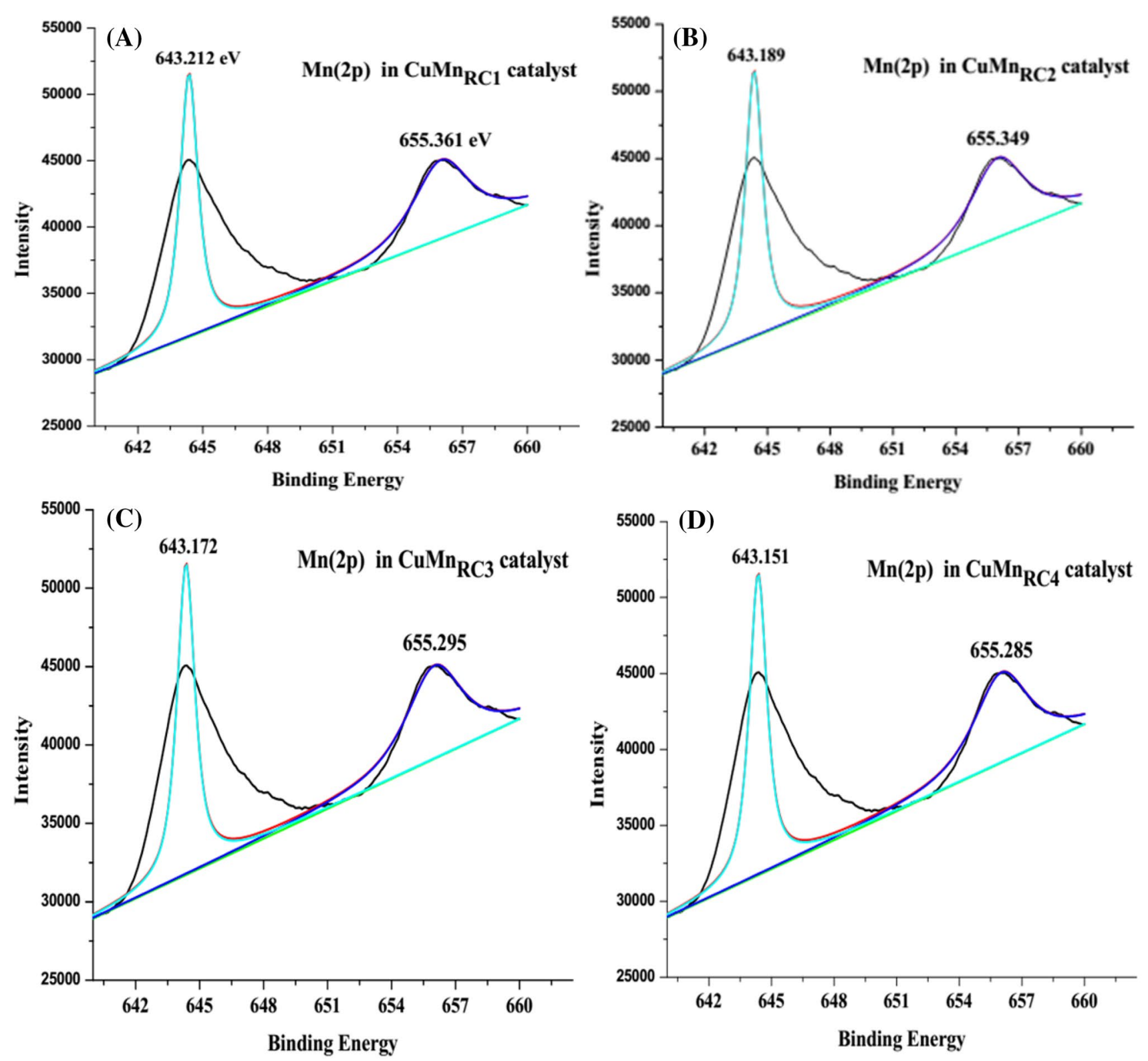

Fig. 7 XPS analysis of $\mathrm{Mn}(2 \mathrm{p})$ in $\mathbf{a} \mathrm{CuMn}_{\mathrm{RC} 1}, \mathbf{b} \mathrm{CuMn}_{\mathrm{RC} 2}, \mathbf{c} \mathrm{CuMn}_{\mathrm{RC} 3}, \mathbf{d} \mathrm{CuMn}_{\mathrm{RC} 4}$

Table 6 Textural property of $\mathrm{CuMn}_{\mathrm{RC}}$ catalysts

\begin{tabular}{llll}
\hline Catalyst & $\begin{array}{l}\text { Surface area } \\
\left(\mathrm{m}^{2} / \mathrm{g}\right)\end{array}$ & $\begin{array}{l}\text { Pore volume } \\
\left(\mathrm{cm}^{3} / \mathrm{g}\right)\end{array}$ & $\begin{array}{l}\text { Avg. pore size } \\
(\AA)\end{array}$ \\
\hline $\mathrm{CuMn}$ & 118.45 & 0.627 & 48.5 \\
$\mathrm{CuMn}$ & 107.51 & 0.572 & 57.5 \\
$\mathrm{CuMn}_{\mathrm{RC} 3}$ & 95.28 & 0.519 & 69.5 \\
$\mathrm{CuMn}_{\mathrm{RC} 4}$ & 88.57 & 0.468 & 79.5 \\
\hline
\end{tabular}

general increase in surface area as a result of choosing suitable precursors.
The average pore diameter was increased with the increase of calcination temperature because a high-temperature treatment led to particle sintering accompanied by a loss in the active area. The $\mathrm{CuMn}_{\mathrm{RC} 1}$ catalyst surface area $\left(118.45 \mathrm{~m}^{2} / \mathrm{g}\right)$ and pore volume $\left(0.627 \mathrm{~cm}^{3} / \mathrm{g}\right)$ were very high, so that it was most active for $\mathrm{CO}$ oxidation at a low temperature. A large number of more pores present in a catalyst surface means a higher number of $\mathrm{CO}$ molecules captured on their surfaces, therefore, it has to shows the better catalytic activity. The specific surface area was measure by BET analysis and it was also followed by the SEM and $\mathrm{XRD}$ results. 

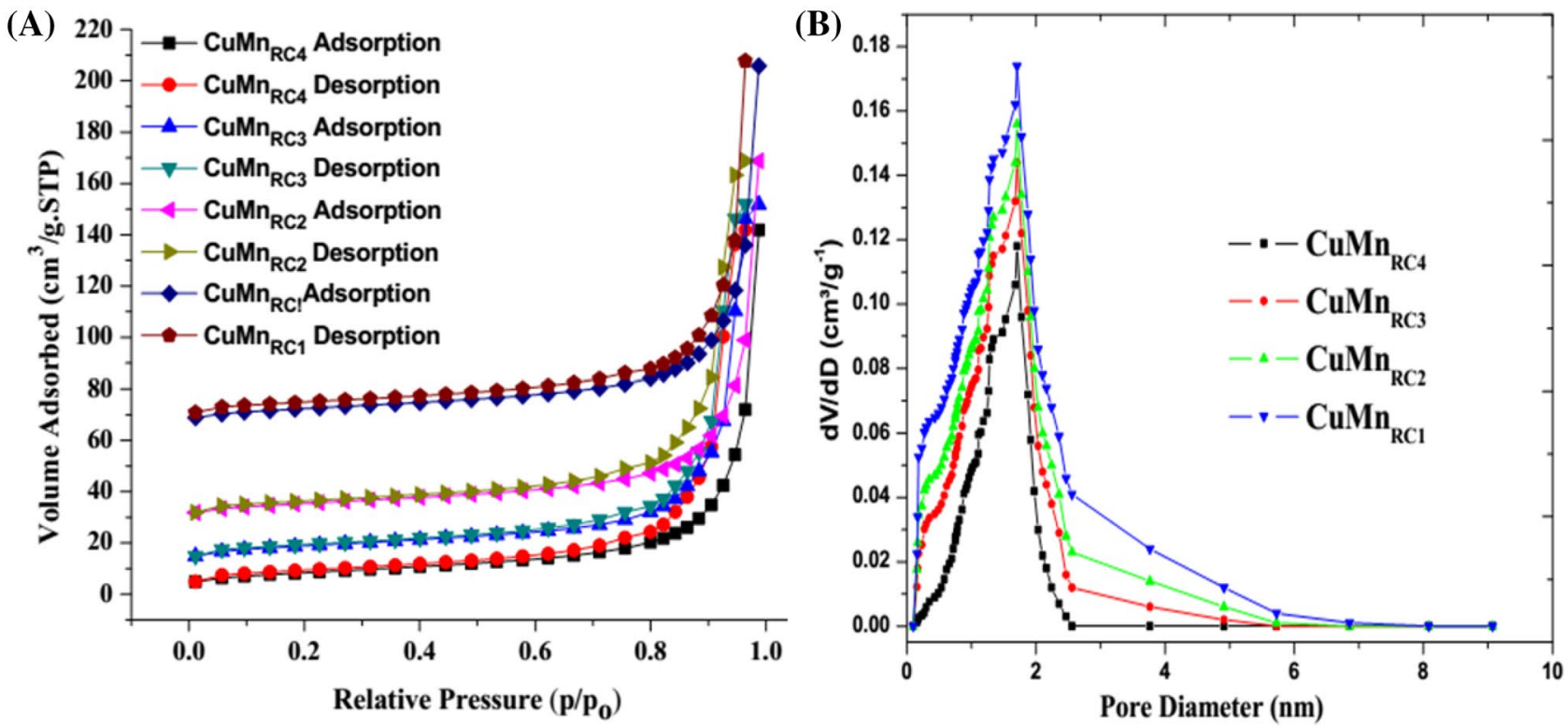

Fig. 8 Textural properties $\mathbf{a} \mathrm{N}_{2}$ adsorption-desorption isotherms and $\mathbf{b}$ Pore size distributions

\section{Catalyst performance and activity measurement}

Activity test of the catalyst was carried out to evaluate the effectiveness of $\mathrm{CuMnOx}$ catalysts as a function of temperature. It was evaluated in different calcination conditions like stagnant air, flowing air and reactive calcination. The activity was increased with the increase of temperature from room temperature to certain high temperature for full conversion of $\mathrm{CO}$. Activity of the $\mathrm{CuMnOx}$ catalysts, produced by co-precipitation method using the different precursors, for the $\mathrm{CO}$ oxidation was discussed below. All the catalysts were highly active for $\mathrm{CO}$ oxidation. The improved catalytic activity of the catalysts can be ascribed to the unique structural, textural characteristics and the smallest crystallite size. The light-off characteristics were used to evaluate the activity of resulting catalysts with the increase of temperature. The characteristic temperature $T_{10}, T_{50}$ and $T_{100}$ correspond to the initiation of oxidation, half conversion and full conversion of $\mathrm{CO}$, respectively.

\section{Stagnant air calcination}

An activity of the $\mathrm{CuMn}_{\mathrm{SA}}$ catalysts was measured in the laboratory at stagnant air calcination conditions for $\mathrm{CO}$ oxidation. The $\mathrm{CO}$ oxidation by $\mathrm{CuMn}_{\mathrm{SA}}$ catalyst was highly influenced by a combination of factors including preparation conditions, drying temperature, calcination conditions and the presence of $\mathrm{Cu}^{2+}, \mathrm{Mn}^{2+}$ and $\mathrm{O}$ on the surface of catalyst. The stagnant air calcination of $\mathrm{CuMnOx}$ precursor was done in a muffle furnace in presence of stagnant air. A clean surface was exposed by a mixture of $\mathrm{CO}$ and air quickly becomes covered with $\mathrm{CO}$ since it requires single vacant adsorption sites. The catalytic activity tests were carried out to evaluate the activity of resulting catalysts as a function of temperature. The interaction between various chemical compounds $(\mathrm{Cu}-\mathrm{Nitrate}$ or $\mathrm{Cu}-$ Acetate and $\mathrm{Mn}-\mathrm{Nitrate}$ or $\mathrm{Mn}$-Acetate) with the precipitation agent $\mathrm{KMnO}_{4}$ as the formation of a highly disordered mixed metal oxide was the cause of high catalytic activity for $\mathrm{CO}$ oxidation.

It was evident from the Table 7 and Fig. 9 that the oxidation of $\mathrm{CO}$ was just initiated near around the room temperature at $25{ }^{\circ} \mathrm{C}$ and $50 \%$ conversion of $\mathrm{CO}$ has occurred at $90{ }^{\circ} \mathrm{C}$ over $\mathrm{CuMn}_{\mathrm{SA} 1}$ catalyst, which was less by $10^{\circ} \mathrm{C}$, $20{ }^{\circ} \mathrm{C}$ and $30{ }^{\circ} \mathrm{C}$ over than that of $\mathrm{CuMn}_{\mathrm{SA} 2}, \mathrm{CuMn}_{\mathrm{SA} 3}$ and $\mathrm{CuMn}_{\mathrm{SA} 4}$ catalyst, respectively. The total oxidation temperature of $\mathrm{CO}$ was $180{ }^{\circ} \mathrm{C}$ for $\mathrm{CuMn}_{\mathrm{SA} 1}$, which was less by $20{ }^{\circ} \mathrm{C}, 30{ }^{\circ} \mathrm{C}$ and $50{ }^{\circ} \mathrm{C}$ over than that of $\mathrm{CuMn}_{\mathrm{SA} 2}, \mathrm{CuMn}_{\mathrm{SA} 3}$ and $\mathrm{CuMn}_{\mathrm{SA} 4}$ catalysts, respectively. Finally, we confirmed that the $\mathrm{CuMn}_{\mathrm{SA} 1}$ catalyst has shown that the best catalytic activity towards $\mathrm{CO}$ oxidation as compared to the other catalysts.

Table 7 Light-off characteristics of $\mathrm{CuMn}_{\mathrm{SA}}$ catalysts

\begin{tabular}{llll}
\hline Catalyst & $\mathrm{T}_{\mathrm{i}}{ }^{\circ} \mathrm{C}$ & $\mathrm{T}_{50}{ }^{\circ} \mathrm{C}$ & $\mathrm{T}_{100}{ }^{\circ} \mathrm{C}$ \\
\hline $\mathrm{CuMn}_{\text {SA1 }}$ & 25 & 90 & 180 \\
$\mathrm{CuMn}_{\text {SA2 }}$ & 25 & 100 & 200 \\
$\mathrm{CuMn}_{\text {SA3 }}$ & 25 & 110 & 210 \\
$\mathrm{CuMn}_{\text {SA4 }}$ & 25 & 120 & 230 \\
\hline
\end{tabular}




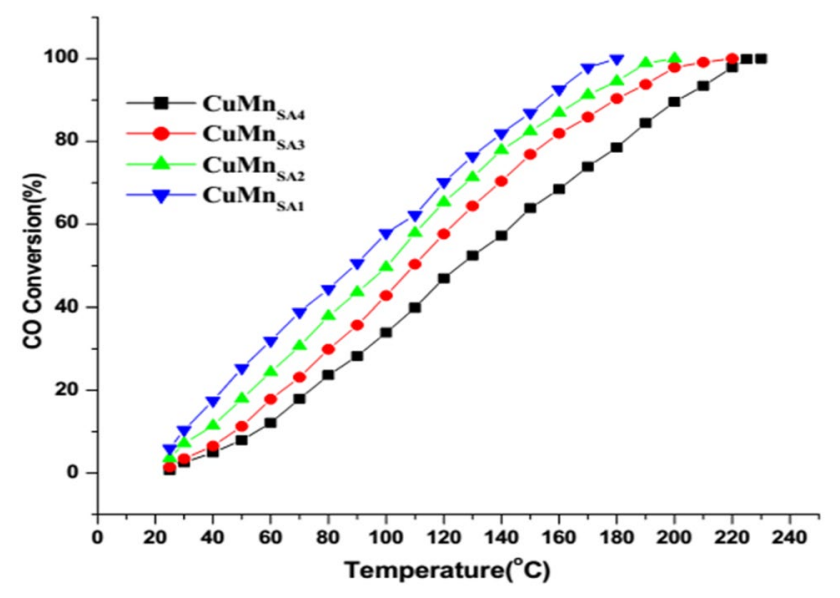

Fig. 9 Catalytic activity of $\mathrm{CuMn}_{\mathrm{SA}}$ catalysts for $\mathrm{CO}$ oxidation

The activity order of each catalyst for CO oxidation was in accordance with their characterization. The order of activity of different types of $\mathrm{CuMnOx}$ catalysts for $\mathrm{CO}$ oxidation was as follows: $\mathrm{CuMn}_{\mathrm{SA} 1}>\mathrm{CuMn}_{\mathrm{SA} 2}>\mathrm{CuMn}_{\mathrm{SA} 3}>\mathrm{CuMn}_{\mathrm{SA} 4}$. Using the same $\left(\mathrm{KMnO}_{4}\right)$ precipitant, the catalysts prepared with a combination of $\left(\left\{\mathrm{Mn}(\mathrm{Ac})_{2}+\mathrm{Cu}\left(\mathrm{NO}_{3}\right)_{2}\right\}\right.$ as the precursors were considerably more effective than the other catalysts. An activity of the multiphase catalysts $\mathrm{CuO}$ and $\mathrm{MnO}_{2}$ were several times higher than those of single-phase oxides CuMnOx catalysts, especially in the lower temperature range. The coordination between $\mathrm{Mn}$ oxide and $\mathrm{Cu}$ oxide in an appropriate proportion with the $\mathrm{CuMnOx}$ catalyst improved their performance for $\mathrm{CO}$ oxidation.

\section{Flowing air calcination}

The copper oxide and manganese oxide were most widely used as precursors in the preparation of various catalysts. The individual property of $\mathrm{Cu}$ oxide and $\mathrm{Mn}$ oxide in $\mathrm{CuM}$ nOx has also an effect on the activity of resulting catalysts [42]. In the flowing air calcination conditions, a fresh catalyst was used to measure the activity of resulting catalysts at each temperature. The increase in local temperature will decrease the decomposition of the precursor. In the initial conditions, a very slow exothermic reaction for $\mathrm{CO}$ oxidation was going on over the catalyst, which causes a rise in the local temperature. The oxidation of $\mathrm{CO}$ was just initiated at $25{ }^{\circ} \mathrm{C}$ in flowing air calcination conditions over all the catalyst samples and $50 \%$ conversion of $\mathrm{CO}$ over the $\mathrm{CuMn} \mathrm{FA}_{\mathrm{FA}}$ catalyst was $70{ }^{\circ} \mathrm{C}$, which was less by $10{ }^{\circ} \mathrm{C}, 30{ }^{\circ} \mathrm{C}$ and $50{ }^{\circ} \mathrm{C}$ over than that of $\mathrm{CuMn}_{\mathrm{FA} 2}, \mathrm{CuMn}_{\mathrm{FA} 3}$ and $\mathrm{CuMn}_{\mathrm{FA} 4}$ catalysts, respectively.

The total oxidation temperature of $\mathrm{CO}$ was $120{ }^{\circ} \mathrm{C}$ for $\mathrm{CuMn}_{\mathrm{FA} 1}$ catalyst, which was less by $30^{\circ} \mathrm{C}, 55^{\circ} \mathrm{C}$ and $70^{\circ} \mathrm{C}$ over than that of $\mathrm{CuMn}_{\mathrm{FA} 2}, \mathrm{CuMn}_{\mathrm{FA} 3}$ and $\mathrm{CuMn}_{\mathrm{FA} 4}$ catalysts, respectively. As compared to stagnant air calcination,
Table 8 Light-off characteristics of $\mathrm{CuMn}_{\mathrm{FA}}$ catalysts

\begin{tabular}{llcl}
\hline Catalyst & $\mathrm{T}_{\mathrm{i}}\left({ }^{\circ} \mathrm{C}\right)$ & $\mathrm{T}_{50}\left({ }^{\circ} \mathrm{C}\right)$ & $\begin{array}{l}\mathrm{T}_{100} \\
\left({ }^{\circ} \mathrm{C}\right)\end{array}$ \\
\hline $\mathrm{CuMn}_{\mathrm{FA} 1}$ & 25 & 70 & 120 \\
$\mathrm{CuMn}_{\mathrm{FA} 2}$ & 25 & 80 & 150 \\
$\mathrm{CuMn}_{\mathrm{FA} 3}$ & 25 & 100 & 175 \\
$\mathrm{CuMn}_{\mathrm{FA} 4}$ & 25 & 120 & 190 \\
\hline
\end{tabular}

the flowing air produced more active catalysts for $\mathrm{CO}$ oxidation at a low temperature. The order of activity for various calcination conditions was as follows: FAC $>$ SAC. The activity of the catalysts seems to be dominated both by their average oxidation numbers and the presence of different species in a catalyst surfaces. The order of activity of different types of $\mathrm{CuMnOx}$ catalysts for $\mathrm{CO}$ oxidation was as follows: $\mathrm{CuMn}_{\mathrm{FA} 1}>\mathrm{CuMn}_{\mathrm{FA} 2}>\mathrm{CuMn}_{\mathrm{FA} 3}>\mathrm{CuMn}_{\mathrm{FA} 4}$. After the activity test, we have observed that the $\mathrm{CuMn}_{\mathrm{FA} 1}$ catalyst has a higher catalytic activity for $\mathrm{CO}$ oxidation, as compared to the other catalysts (Table 8).

Keeping the same precipitant while changing the precursor had a significant influence on the CO oxidation activity. The catalysts prepared by a combination of $\left\{\mathrm{Mn}(\mathrm{Ac})_{2}+\mathrm{Cu}\left(\mathrm{NO}_{3}\right)_{2}\right\}$ as precursors were considerably more active than the other catalysts. With the same precipitant, the catalysts prepared with $\mathrm{Mn}$-acetate as a part of the precursor resulted in a better catalytic activity than the Mn-nitrates. A suitable combination of various chemical compounds present in the precursor resulted in the most efficient CO oxidation catalyst. The preparation of catalyst was highly influenced by their structure and activity. CO was rapidly adsorbed and occupies the active sites on the CuMnOx catalyst's surface during the completing adsorption process.

\section{Reactive calcination}

The RC process minimized a process step by converting twostep processes into single-step process in a reactive $\mathrm{CO}$-air mixture at $300{ }^{\circ} \mathrm{C}$. It also produced $\mathrm{CuMn}_{\mathrm{RC}}$ catalysts with improved performance for $\mathrm{CO}$ oxidation. In the beginning, a very slow exothermic oxidation of $\mathrm{CO}$ over the precursor's crystallites started causing a small rise in the local temperature, ensuing decomposition of the precursor also (Fig. 10).

The oxidation of $\mathrm{CO}$ was just initiated in reactive calcination conditions at $25{ }^{\circ} \mathrm{C}$ over all the catalyst samples and $50 \%$ conversion of $\mathrm{CO}$ over the $\mathrm{CuMn}_{\mathrm{RC} 1}$ catalyst was $45^{\circ} \mathrm{C}$, which was less by $10^{\circ} \mathrm{C}, 25^{\circ} \mathrm{C}$ and $40{ }^{\circ} \mathrm{C}$ over than that of $\mathrm{CuMn}_{\mathrm{RC} 2}, \mathrm{CuMn}_{\mathrm{RC} 3}$ and $\mathrm{CuMn}_{\mathrm{RC} 4}$ catalysts, respectively. The total oxidation temperature of $\mathrm{CO}$ was $80^{\circ} \mathrm{C}$ for $\mathrm{CuMn}_{\mathrm{RC} 1}$ catalyst, which was less by $20^{\circ} \mathrm{C}, 35^{\circ} \mathrm{C}$ and $50{ }^{\circ} \mathrm{C}$ over than that of $\mathrm{CuMn}_{\mathrm{RC} 2}, \mathrm{CuMn}_{\mathrm{RC} 3}$ and $\mathrm{CuMn}_{\mathrm{RC} 4}$ 


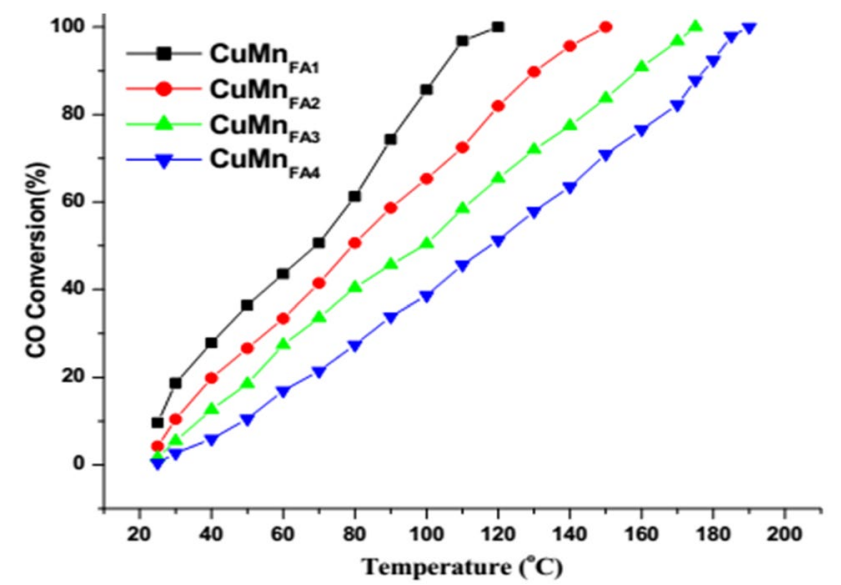

Fig. 10 Catalytic activity of $\mathrm{CuMn}_{\mathrm{FA}}$ catalysts for $\mathrm{CO}$ oxidation

Table 9 Light-off characteristics of $\mathrm{CuMn}_{\mathrm{RC}}$ catalysts

\begin{tabular}{lllc}
\hline Catalyst & $\mathrm{T}_{\mathrm{i}}\left({ }^{\circ} \mathrm{C}\right)$ & $\mathrm{T}_{50}\left({ }^{\circ} \mathrm{C}\right)$ & $\mathrm{T}_{100}\left({ }^{\circ} \mathrm{C}\right)$ \\
\hline $\mathrm{CuMn}_{\mathrm{RC} 1}$ & 25 & 45 & 80 \\
$\mathrm{CuMn}_{\mathrm{RC} 2}$ & 25 & 55 & 100 \\
$\mathrm{CuMn}_{\mathrm{RC} 3}$ & 25 & 70 & 115 \\
$\mathrm{CuMn}_{\mathrm{RC} 4}$ & 25 & 85 & 130 \\
\hline
\end{tabular}

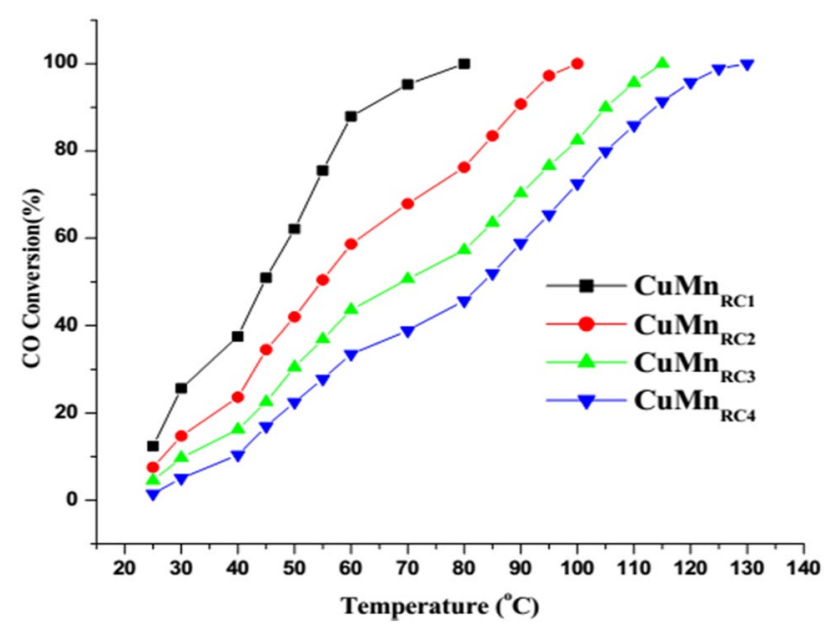

Fig. 11 Catalytic activity of $\mathrm{CuMn}_{\mathrm{RC}}$ catalysts for $\mathrm{CO}$ oxidation

catalysts, respectively. It was clear from the Table 9 and Fig. 11 that the $\mathrm{CuMn}_{\mathrm{RC} 1}$ catalyst has shown that the best catalytic activity towards $\mathrm{CO}$ oxidation as compared to the other catalysts. The order of activity of different types of $\mathrm{CuMnOx}$ catalysts for $\mathrm{CO}$ oxidation was as follows: $\mathrm{CuMn}_{\mathrm{RC} 1}>\mathrm{CuMn}_{\mathrm{RC} 2}>\mathrm{CuMn}_{\mathrm{RC} 3}>\mathrm{CuMn}_{\mathrm{RC} 4}$. With the same precipitant, the catalysts prepared by $\mathrm{Cu}-\mathrm{Nitrate}$ as a part of the precursor resulted in a better catalytic activity than the catalyst prepared by $\mathrm{Cu}-$ Acetate as a precursor.

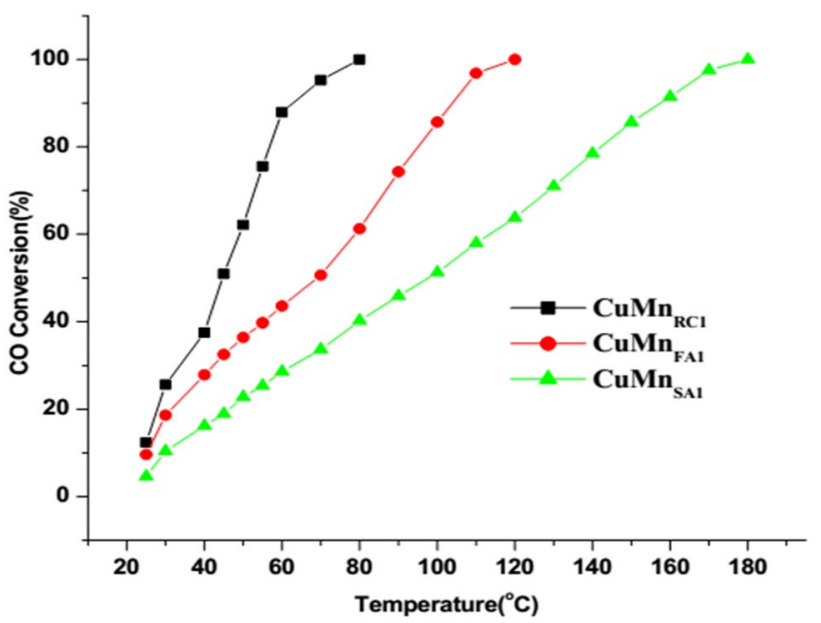

Fig. 12 Activity test of CuMnOx catalysts under various calcination conditions

The presence of $\mathrm{Mn}-$ Acetate and $\mathrm{Cu}-\mathrm{Nitrate}$ in the $\mathrm{CuMn}_{\mathrm{RC} 1}$ precursor has shown the best catalytic activity towards $\mathrm{CO}$ oxidation. After the activity test, we can propose that the $\mathrm{CuMn}_{\mathrm{RC} 1}$ catalyst has a higher catalytic activity for $\mathrm{CO}$ oxidation as compared to the other catalysts. The $\mathrm{CuMn}_{\mathrm{RC} 1}$ catalyst has shown a promising performance for $\mathrm{CO}$ oxidation at a low temperature and these systems were now worthy for further investigation.

\section{Comparison of reactive calcination with traditional calcination}

The $\mathrm{RC}$ route was the most appropriate calcination strategy for the production of highly active $\mathrm{CuMnOx}$ catalyst for $\mathrm{CO}$ oxidation. A comparative study of $\mathrm{CO}$ oxidation over the $\left(\mathrm{CuMn}_{\mathrm{SA} 1}, \mathrm{CuMn}_{\mathrm{FA} 1}\right.$ and $\left.\mathrm{CuMn}_{\mathrm{RC} 1}\right)$ catalysts produced under the various calcination conditions of stagnant air, flowing air and RC are shown in the Fig. 12. The calcination strategies have a drastic effect on the activity of resulting catalyst. The oxidation of $\mathrm{CO}$ was just initiated at $25{ }^{\circ} \mathrm{C}$ over all the catalyst samples and $50 \%$ conversion of $\mathrm{CO}$ over the $\mathrm{CuMn} \mathrm{RC}_{\mathrm{R} 1}$ catalyst was $45^{\circ} \mathrm{C}$, which was less by $25{ }^{\circ} \mathrm{C}$ and $45^{\circ} \mathrm{C}$ over than that of $\mathrm{CuMn}_{\mathrm{FA} 1}$ and $\mathrm{CuMn}_{\mathrm{SA} 1}$ catalysts, respectively. The complete conversion of $\mathrm{CO}$ has occurred at $80^{\circ} \mathrm{C}$ for $\mathrm{CuMn}_{\mathrm{RC} 1}$ catalyst, which was less by $40{ }^{\circ} \mathrm{C}$ and $100{ }^{\circ} \mathrm{C}$ over than that of $\mathrm{CuMn}_{\mathrm{SA} 1}$ and $\mathrm{CuMn}_{\mathrm{FA} 1}$ catalysts, respectively. The activity order for $\mathrm{CO}$ oxidation in the decreasing sequence was in accordance with their characterization by SEM-EDX, BET, XRD, XPS and FTIR as follows: $\mathrm{CuMn}_{\mathrm{RCl}}>\mathrm{CuMn}_{\mathrm{FAl}}>\mathrm{CuMn}_{\mathrm{SA} 1}$. The improved catalytic activity of the catalyst can be ascribed to the unique structural and textural characteristics as the smallest crystallites of $\mathrm{CuMn}_{\mathrm{RCl}}$. The highly dispersed and specific surface area which could expose more active sites 
Table 10 Light-off characteristics of $\mathrm{CuMn}_{1}$ catalysts

\begin{tabular}{lllc}
\hline Catalyst & $\mathrm{T}_{\mathrm{i}}\left({ }^{\circ} \mathrm{C}\right)$ & $\mathrm{T}_{50}\left({ }^{\circ} \mathrm{C}\right)$ & $\mathrm{T}_{100}\left({ }^{\circ} \mathrm{C}\right)$ \\
\hline $\mathrm{CuMn}_{\mathrm{SA} 1}$ & 25 & 90 & 180 \\
$\mathrm{CuMn}_{\mathrm{FA} 1}$ & 25 & 70 & 120 \\
$\mathrm{CuMn}_{\mathrm{RC} 1}$ & 25 & 45 & 80 \\
\hline
\end{tabular}

for the catalytic oxidation and relatively open-textured pores will favor the adsorption of reactants and desorption of products and thus facilitate the oxidation process. The order of activity for various calcination conditions was as follows: $\mathrm{RC}>\mathrm{FAC}>\mathrm{SAC}$.

The partial reduction phases were provided oxygen deficient on defective structure, which also created high density for active sites in reactive calcinations process, as a result $\mathrm{CuMn}_{\mathrm{RC} 1}$ turned into the most active catalyst [14]. The highest activity of $\mathrm{CuMn}_{\mathrm{RC} 1}$ was associated with the formation of smallest crystallites authenticated by XRD observation. Using the CuMnOx catalyst, the precursors have changed the high influence activity of the resulting catalysts. Finally, it was found that the various precursors could lead to different crystalline phase formations of the $\mathrm{CuMnOx}$ catalysts (Table 10).

The results were confirmed by matching with the XRD, FTIR, and BET analysis. The combination of precipitant and precursor in the precipitation process plays a significant role in producing the highly active catalyst. It was postulated that during the RC method, concurrent multifarious phenomena of $\mathrm{CO}$ oxidation and the precursor decomposition cause a synergistic effect in the formation of oxygen-deficient catalyst structure at a low temperature. The calcination strategies influenced the physicochemical properties and catalytic performance of CuMnOx catalysts for $\mathrm{CO}$ oxidation [43, 44].

\section{Stability test}

The stability test of $\mathrm{CuMn}_{\mathrm{RC} 1}$ catalyst was conducted at $80{ }^{\circ} \mathrm{C}$ for oxidation of $\mathrm{CO}$ in a continuous running for $48 \mathrm{~h}$ under the earliest mentioned experimental conditions. The result revealed that practically $2 \%$ deactivation of the $\mathrm{CuMn}_{\mathrm{RC} 1}$ catalyst has occurred in the experiments' conditions. The conversion of $\mathrm{CO}$ changed from 100 to $98 \%$ with the increase of time up to $48 \mathrm{~h}$. The extraordinary performance of $\mathrm{CuMn}_{\mathrm{RC} 1}$ catalyst produced by $\mathrm{RC}$ for $\mathrm{CO}$ oxidation was associated with the modification in intrinsic textural, morphological characteristics such as surface area, crystallite size, and particle size of the catalyst. The main objective of this study was to evaluate the stability of $\mathrm{CuMn}_{\mathrm{RC} 1}$ catalyst as well as their importance for $\mathrm{CO}_{2}$ formation.

\section{Conclusions}

The CuMnOx catalysts have been synthesized using $\left\{\mathrm{Mn}(\mathrm{Ac})_{2}+\mathrm{Cu}\left(\mathrm{NO}_{3}\right)_{2}\right\}, \quad\left\{\mathrm{Mn}(\mathrm{Ac})_{2}+\mathrm{Cu}(\mathrm{Ac})_{2}\right\}$, $\left\{\mathrm{Mn}\left(\mathrm{NO}_{3}\right)_{2}+\mathrm{Cu}\left(\mathrm{NO}_{3}\right)_{2}\right\},\left\{\mathrm{Mn}\left(\mathrm{NO}_{3}\right)_{2}+\mathrm{Cu}(\mathrm{AC})_{2}\right\}$ as precursor precipitated by $\mathrm{KMnO}_{4}$ solution and their catalytic activity for $\mathrm{CO}$ oxidation have been evaluated. The various precursors had a significant influence on the structural properties and their catalytic activity for $\mathrm{CO}$ oxidation. The catalyst prepared by $\left\{\mathrm{Mn}(\mathrm{Ac})_{2}+\mathrm{Cu}\left(\mathrm{NO}_{3}\right)_{2}\right\}$ as a precursor exhibited the best catalytic activity towards $\mathrm{CO}$ oxidation due to their high oxygen mobility. Maintaining the same precipitant, while changing the precursor causes a small change in the quantity of active sites which influence the $\mathrm{CO}$ oxidation activity. The calcination strategies of the precursor have a great influence on the activity of resulting catalysts. The calcination order with respect to the performance of catalysts for $\mathrm{CO}$ oxidation was as follows: reactive calcination $>$ flowing air $>$ stagnant air. The $\mathrm{RC}$ route was the most appropriate calcination strategy for the production of highly active $\mathrm{CuMn}_{\mathrm{RC} 1}$ catalyst for $\mathrm{CO}$ oxidation. It was in accordance with their characterization. The performance of this catalyst was judged by their activity, selectivity, and stability. Finally, we conclude that the choice of precursors in the catalyst is important in designing the most efficient $\mathrm{CO}$ oxidation catalyst.

Open Access This article is distributed under the terms of the Creative Commons Attribution 4.0 International License (http://creativeco mmons.org/licenses/by/4.0/), which permits unrestricted use, distribution, and reproduction in any medium, provided you give appropriate credit to the original author(s) and the source, provide a link to the Creative Commons license, and indicate if changes were made.

\section{References}

1. Singh P, Prasad R (2014) Catalytic abatement of cold start vehicular CO emissions. Catal Ind 6(2):122-127

2. Dey S, Dhal GC, Prasad R, Mohan D (2016) Effect of nitrate metal $(\mathrm{Ce}, \mathrm{Cu}, \mathrm{Mn}$ and $\mathrm{Co}$ ) precursors for the total oxidation of carbon monoxide. Resour Effic Technol 3:293-302

3. Cholakov GS (2010) Control of exhaust emissions from internal combustion engine vehicles. Pollut Control Technol 3:1-8

4. Mishra A, Prasad R (2014) Preparation and application of perovskite catalysts for diesel soot emissions control: an overview. Catal Rev Sci Eng 56:57-81

5. Katz M (1953) The heterogeneous oxidation of carbon monoxide. Adv Catal 5:177-216

6. Cai L, Guo Y, Lu A, Branton P, Li W (2012) The choice of precipitant and precursor in the co-precipitation synthesis of copper manganese oxide for maximizing carbon monoxide oxidation. $\mathbf{J}$ Mol Catal A Chem 360:35-41

7. Kramer M, Schmidt T, Stowe K, Maier WF (2006) Structural and catalytic aspects of sol-gel derived copper manganese oxides as low-temperature $\mathrm{CO}$ oxidation catalyst. Appl Catal A 302:257-263 
8. Huang T, Tsai D (2003) CO oxidation behavior of copper and copper oxides. Catal Lett 87:173-178

9. Spivey JJ (1987) Complete catalytic oxidation of volatile organics. Am Chem Soc 26:2165-2180

10. Zhou Y, Wang Z, Liu C (2014) Perspective on CO oxidation over Pd-based catalysts. Catal Sci Technol 5:69-81

11. Wang S, Zheng X, Wang X, Wang S, Zhang S, Yu L, Huang W, Wu S (2005) Comparison of $\mathrm{CuO} / \mathrm{Ce}_{0.8} \mathrm{Zr}_{0.2} \mathrm{O}_{2}$ and $\mathrm{CuO} /$ $\mathrm{CeO}_{2}$ catalysts for low-temperature $\mathrm{CO}$ oxidation. Catal Lett 105(3-4):163-168

12. Santra AK, Goodman DW (2002) Catalytic oxidation of CO by platinum group metals: from ultrahigh vacuum to elevated pressures. Electrochim Acta 47:3595-3609

13. Solsona B, Hutchings GJ, Garcia T, Taylor SH (2004) Improvement of the catalytic performance of $\mathrm{CuMnOx}$ catalysts for $\mathrm{CO}$ oxidation by the addition of Au. New J Chem 28:708-711

14. Hutchings GJ, Mirzaei AA, Joyner RW, Siddiqui MRH, Taylor SH (1996) Ambient temperature CO oxidation using copper manganese oxide catalysts prepared by co-precipitation: effect of ageing on catalyst performance. Catal Lett 42:21-24

15. Jones C, Cole KJ, Taylor SH, Crudace MJ, Hutchings GJ (2009) Copper manganese oxide catalysts for ambient temperature carbon monoxide oxidation: effect of calcination on activity. J Mol Catal A Chem 305:121-124

16. Tanaka Y, Utaka T, Kikuchi R, Takeguchi T, Sasaki K, Eguchi K (2003) Water gas shift reaction for the reformed fuels over $\mathrm{Cu} / \mathrm{MnO}$ catalysts prepared via spinel-type oxide. J Catal 215:271-278

17. Peng CT, Lia HK, Liaw BJ, Chen YZ (2011) Removal of CO in excess hydrogen over $\mathrm{CuO} / \mathrm{Ce}_{1-\mathrm{X}} \mathrm{MnxO}_{2}$ catalysts. Chem Eng $\mathrm{J}$ $172: 452-458$

18. Lee J, Kim H, Lee H, Jang S, Chang JH (2016) Highly efficient elimination of carbon monoxide with binary copper-manganese oxide contained ordered nanoporous silicas. Nanoscale Res Lett $11: 2-6$

19. Dey S, Dhal GC, Prasad R, Mohan D (2017) Effects of doping on the performance of CuMnOx Catalyst for $\mathrm{CO}$ oxidation. Bull Chem React Eng Catal 12(3):1-14

20. Qian K, Qian Z, Hua Q, Jiang Z, Huang W (2013) Structure activity relationship of $\mathrm{CuO} / \mathrm{MnO}_{2}$ catalysts in $\mathrm{CO}$ oxidation. Appl Surf Sci 273:357-363

21. Irawan RB, Purwanto P, Hadiyanto H (2015) Optimum design of manganese-coated copper catalytic converter to reduce carbon monoxide emissions on gasoline motors. Int Conf Trop Coast Reg Eco-Dev 23:86-92

22. Marinoiu A, Raceanu M, Cobzaru C, Teodorescu C, Marinescu D, Soare A, Varlam M (2014) Low temperature CO retention using hopcalite catalyst for fuel cell applications. React Kinet Mech Catal 112:37-50

23. Hu Y, Dong L, Wang J, Ding W, Chen Y (2000) Activities of supported copper oxide catalysts in the $\mathrm{NO}+\mathrm{CO}$ reaction at low temperatures. J Mol Catal A Chem 162:307-316

24. Liu Y, Guo Y, Peng H, Xu X, Wu Y, Peng C, Zhang N, Wang X (2016) Modifying Hopcalite catalyst by $\mathrm{SnO}_{2}$ addition: an effective way to improve its moisture tolerance and activity for low temperature CO oxidation. Appl Catal A 525:204-214

25. Mokhtar M, Basahel SN, Al-Angary YO (2010) Nanosized spinel oxide catalysts for $\mathrm{CO}$-oxidation prepared via $\mathrm{CoMnMgAl}$ quaternary hydrotalcite route. J Alloy Compd 493:376-384

26. Choi K, Lee D, Kim H, Yoon Y, Park C, Kim YH (2016) Reaction characteristics of precious-metal-free ternary $\mathrm{Mn}-\mathrm{Cu}-\mathrm{M}$ $(\mathrm{M}=\mathrm{Ce} \mathrm{Co}, \mathrm{Cr}$, and $\mathrm{Fe}$ ) oxide catalysts for low-temperature $\mathrm{CO}$ oxidation. Ind Eng Chem Res 55:4443-4450

27. Larsson P, Andersson A (2000) Oxides of copper, ceria promoted copper, manganese and copper manganese on $\mathrm{Al}_{2} \mathrm{O}_{3}$ for the combustion of $\mathrm{CO}$, ethyl acetate and ethanol. Appl Catal B 24:175-192
28. Dey S, Dhal GC, Mohan D, Prasad R (2017) Kinetics of catalytic oxidation of carbon monoxide over CuMnAgOx Catalyst. Mater Discov 8:18-25

29. Dey S, Dhal GC, Mohan D, Prasad R (2017) Study of Hopcalite $(\mathrm{CuMnOx})$ catalysts prepared through a novel route for the oxidation of carbon monoxide at low temperature. Bull Chem React Eng Catal 12(3):393-407

30. Njagi EC, Chen C, Genuino H, Galindo H, Huang H, Suib SL (2010) Total oxidation of CO at ambient temperature using copper manganese oxide catalysts prepared by a redox method. Appl Catal A 99:103-110

31. Dey S, Dhal GC, Mohan D, Prasad R (2017) Characterization and activity of $\mathrm{CuMnOx} / \gamma-\mathrm{Al}_{2} \mathrm{O}_{3}$ catalyst for oxidation of carbon monoxide. Mater Discov 8:26-34

32. Dey S, Dhal GC, Prasad R, Mohan D (2016) Total oxidation of $\mathrm{CO}$ by CuMnOx catalyst at a low temperature. Int J Sci Eng Res 7(10):1730-1737

33. Zhang XD, Hou FL, Li HX, Yang Y, Wang YX, Liu N, Yang YQ (2018) A strawsheave-like metal organic framework CeBTC derivative containing high specific surface area for improving the catalytic activity of $\mathrm{CO}$ oxidation reaction. Microporous Mesoporous Mater 259:211-219

34. Dey S, Dhal GC, Mohan D, Prasad R (2017) Effect of preparation conditions on the catalytic activity of $\mathrm{CuMnOx}$ catalysts for $\mathrm{CO}$ oxidation. Bull Chem React Eng Catal 12(3):437-451

35. Zhang XD, Li HX, Yang Y, Zhang TT, Wen X, Liu N, Wang DJ (2017) Facile synthesis of new efficient $\mathrm{Cu} / \mathrm{MnO}_{2}$ catalysts from used battery for CO oxidation. J Environ Chem Eng 5:5179-5186

36. Yang YQ, Dong H, Wang Y, Wang YX, Liu N, Wang DJ, Zhang $\mathrm{XD}$ (2017) A facile synthesis for porous $\mathrm{CuO} / \mathrm{Cu}_{2} \mathrm{O}$ composites derived from MOFs and their superior catalytic performance for CO oxidation. Inorg Chem Commun 86:74-77

37. Zhang XD, Li HX, Hou FL, Yang Y, Dong H, Liu N, Wang YX, Cui LF (2017) Synthesis of highly efficient $\mathrm{Mn}_{2} \mathrm{O}_{3}$ catalysts for CO oxidation derived from Mn-MIL-100. Appl Surf Sci 411:27-33

38. Zhang XD, Hou FL, Yang Y, Wang YX, Liu N, Chen D, Yang YQ (2017) A facile synthesis for cauliflower like $\mathrm{CeO}_{2}$ catalysts from Ce-BTC precursor and their catalytic performance for $\mathrm{CO}$ oxidation. Appl Surf Sci 423:771-779

39. Cui LF, Zhao D, Yang Y, Wang YX, Zhang XD (2017) Synthesis of highly efficient $\alpha-\mathrm{Fe}_{2} \mathrm{O}_{3}$ catalysts for $\mathrm{CO}$ oxidation derived from MIL-100(Fe). J Solid State Chem 247:168-172

40. Zhang XD, Dong H, Wang Y, Liu N, Zuo YH, Cui LF (2016) Study of catalytic activity at the Ag/Al-SBA-15 catalysts for CO oxidation and selective CO oxidation. Chem Eng J 283:1097-1107

41. Dey S, Dhal GC, Mohan D, Prasad R, Gupta RN (2018) Cobalt doped CuMnOx catalysts for the preferential oxidation of carbon monoxide. Appl Surf Sci 441:303-316

42. Yang YQ, Hou FL, Li HX, Liu N, Wang Y, Zhang XD (2017) Facile synthesis of Ag/KIT-6 catalyst via a simple one pot method and application in the CO oxidation. J Porous Mater 24:1661-1665

43. Dey S, Dhal GC, Mohan D, Prasad R (2018) Low-temperature complete oxidation of $\mathrm{CO}$ over various manganese oxide catalyst. Atmos Pollut Res 9:755-763

44. Dey S, Dhal GC, Mohan D, Prasad R (2018) Copper based mixed oxide catalysts (CuMnCe, $\mathrm{CuMnCo}$ and $\mathrm{CuCeZr}$ ) for the oxidation of CO at low temperature. Mater Discov 10:1-14

Publisher's Note Springer Nature remains neutral with regard to jurisdictional claims in published maps and institutional affiliations. 